Original Research Paper

\title{
Synthesis, Ant Proliferative Activity and Docking Study of New Quercetin Derivatives against MDA-MB231 Breast Cancer Cell Lines
}

\author{
Reham Adnan Al-Anssari, Rita S. Elias and Shaker A.N. Aljadaan \\ Department of Pharmaceutical Chemistry, College of Pharmacy, University of Basrah, Basrah, Iraq
}

\author{
Article history \\ Received: 27-04-2019 \\ Revised: 28-05-2019 \\ Accepted: 22-06-2019 \\ Corresponding Author: \\ Rita S. Elias \\ Department of Pharmaceutical \\ Chemistry, College of \\ Pharmacy, University of \\ Basrah, Basrah, Iraq \\ Tel: +964770809855 \\ Email: rita_phar@yahoo.com
}

\begin{abstract}
MDA-MB231 is a very aggressive and invasive triple negative breast cancer, which present with limited treatment options. Unlike other breast cancer types, it is characterized by absence of hormonal receptors of estrogen, progesterone as well as human epidermal growth factor receptor 2, rendering it unsuitable for hormonal therapy and a perfect candidate for chemotherapy. Quercetin is a common natural flavonoid present in many food items, which have a wide range of biological activities, likes anticancer, antiviral, antibacterial and antioxidant. This study involves the synthesis of new Quercetin derivatives and the investigation their effects against MDAMB231 cell lines. The structures of the derivatives were established using UV, IR, ${ }^{1}$ HNMR, CHNS, EIMS and ESIMS techniques. Their antiproliferative activities were investigated in vitro using Microculture Tetrazolium (MTT) assay. The percentage cell viability following exposure to Quercetin and its derivatives (Compounds 1-5) were measured. Both compounds $\mathbf{1}$ and $\mathbf{4}$ show a significant decrease in percentage cell viability from $100 \%$ to $43.7 \%$ and $38.1 \%$ respectively. $\mathrm{IC}_{50}$ value was calculated for compound $\mathbf{1}$ and $\mathbf{4}$ and found to be 2.042 and 1.838 $\mu \mathrm{M}$ respectively, indicating that they have a potential anticancer activity against the triple negative breast cancer type. The antiproliferative activity was supported and evidenced by molecular docking study.
\end{abstract}

Keywords: Quercetin, MDA-MB231, Molecular Docking, MTT Assay

\section{Introduction}

Triple Negative Breast Cancer (TNBC) is a cancer type that is devoid of the three typical types of receptors known to stimulate most breast cancer growth; estrogen, progesterone and human Epidermal Growth Factor Receptor 2 (EGFR2). Due to the absence of necessary receptors, common hormonal therapy and drugs that target these receptors are ineffective. However, TNBC is considered perfect candidate for chemotherapy as stated by (Chavez et al., 2010). Although Triple negative breast cancer accounts for only $15 \%$ of other breast cancer subtypes, it shows high rate of recurrence and develops resistance to chemotherapy as previously reported by (Rakha et al., 2008). In addition, patients have shown poor prognosis due to the lack of specific targeted therapy (Nguyen et al., 2017). Therefore, it is vital to look for new therapeutic agents that are effective, less toxic and can prevent relapse emergence. Quercetin is 3, 3', 4', 5, 7-pentahydroxyflavone (Fig. 1) which is a natural ploy phenolic compound that belongs to the flavanol class of flavonoids and present within various concentrations in different vegetables and fruits such as onion, broccoli, apple, garlic and tomatoes (AlJabban et al., 2015; Hertog et al., 1992). Quercetin characterize by powerful antioxidant activity and wide pharmacological applications including various antiproliferative activities against colon, pancreatic, prostate, brain, bone, gastric and breast cancer (Rauf et al., 2018), in addition to its antimicrobial, antiinflammatory, antidiabetic, neuroprotective, antiobesity and the prevention of cardiovascular disease activities (Amic et al., 2007; D'Andrea, 2015; Dajas, 2012; Massi et al., 2017; Moalin et al., 2011; Pietta, 2000; Procházková et al., 2011; Ramos et al., 2006; Wang et al., 2006). 


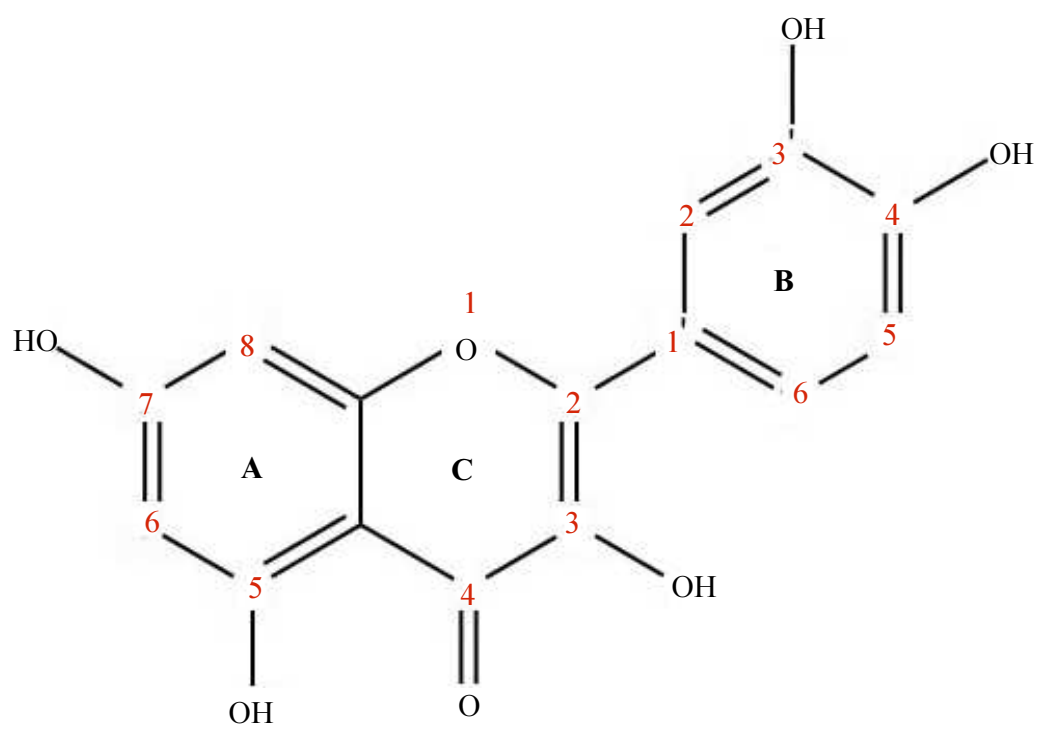

Fig. 1: Quercetin chemical structure

Previous studies have focused on the relationship between anticancer activity of quercetin and the methylation of its five hydroxyl groups and the results have shown the importance of methylation at $4^{\prime}$ and 7 position and at $3^{\prime}$ and $4 '$ positions on the anticancer activity of Quercetin against SKBR breast cancer cell line (Zhi-Hao et al., 2014) while other studies revealed that 3,3',4',7-tetra-O-methylated Quercetin and 3,3',4',5,7-penta-O-methylated Quercetin have the ability to influence the Breast Cancer Resistance Protein (BCRP) which is considered as potential antimultidrug resistant (MDR) protein (Juvale et al., 2013; Yuan et al., 2012). The insertion of methoxy groups into the Quercetin molecule results in an improvement of its physicochemical properties, such as increasing its metabolic stability, solubility and bioavailability as well as reduction of toxic side effects (Walle, 2009). This study is focused on the methylation of its five hydroxyl groups and the replacement of the carbonyl group by 4-thion, 4-thionmethyliodide and 4$\mathrm{C}=\mathrm{N}-\mathrm{R}$ groups. These modifications in Quercetin structure are likely to induce the most important variations in the general electronic and lipophilic properties of the whole molecule. This study revealed some new potent compounds against MDA-MB231 breast cancer cell line.

The work involves the synthesis of six Quercetin derivatives four of them are novel compounds including three Schiff bases of pentamethoxy-quercetin and a 4-thiomethyliodide penta methoxy-quercetin. The synthesized compounds were tested for their anticancer activity against MDA-MB231 breast cancer cell line using MTT assay method. A docking study was conducted to shed more light on their activity.

\section{Materials and Methods}

\section{Reagents}

Quercetin, dimethyl sulfate, Phosphorous pentasulfide, potassium carbonate, acetone (99\%), methanol (99\%), toluene (99\%), sodium sulfate, anisole, molecular sieve $3 \AA$, ethanol (99\%), aniline, methyl iodide and hydrazine hydrate were purchased from SigmaAldrich. Ether, chloroform and cyclohexane from BDH, while dichloromethane was obtained from Ajax chemicals Ltd. All chemicals were used as supplied without further purification.

\section{Chemical Synthesis}

\section{Synthesis of Compound 1}

Compound 1 was synthe-sized following the procedure described by (Picq et al., 1982) as shown in Fig. 2.

In $1 \mathrm{~L}$ round bottomed flask connected to a reflux condenser and calcium chloride tube, Quercetin (10 g, $33 \mathrm{mmol}$ ), $700 \mathrm{~mL}$ acetone (dried on molecular sieves $3 \AA$ ) and anhydrous potassium carbonate (150 g, 5000 $\mathrm{mmol})$ were placed. Stirring was started and dimethyl sulfate $(50 \mathrm{~mL}, 400 \mathrm{mmol})$ was added followed by heating the reaction to reflux for $21 \mathrm{~h}$. The reaction mixture was then filtered off and the solid potassium carbonate was washed with hot acetone three times followed by evaporation of the collected filtrate to dryness using rotary evaporator at $50^{\circ} \mathrm{C}$. The crude product was then recrystallized from methanol, giving powder of compound 1, 2-(3', 4'-dimethoxyphenyl)-3, 5, 7-trimethoxy - 4H-chromen-4 one. 
<smiles>O=c1c(O)c(-c2ccc(O)c(O)c2)oc2cc(O)cc(O)c12</smiles>

Quercetin

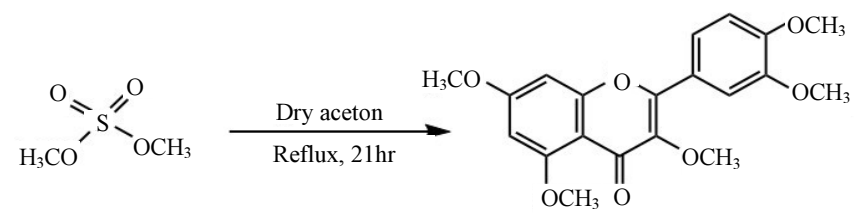

Compound 1

Fig. 2: General Method for the preparation of compound1

\section{Synthesis of Compound 2}

Compound $\mathbf{2}$ was prepared by the reaction of compound 1 with Lawesson's reagent as described by (Ravishankar et al., 2015) (with modification). Lawesson's reagent has been prepared according to (Thomsen et al., 1984).

Compound 1 (0.6 g, $1.59 \mathrm{mmol})$ was dissolved in anhydrous toluene $(15 \mathrm{~mL})$ was added and the reaction was heated to $110^{\circ} \mathrm{C}$ followed by Lawesson's reagent $(0.63$, $1.59 \mathrm{mmol}$ ) addition and refluxing for $180 \mathrm{~min}$. After that the reaction mixture was cooled to room temperature, filtered and the precipitate was purified by column chromatography using silica gel and chloroform $100 \%$ as eluent to obtain compound 2, 2-(3',4'-Dimethoxyphenyl)3,5,7-trimethoxy-4H-chromene-4-thione.

\section{Synthesis of Schiff's Bases}

Schiff's bases of pentamethoxy quercetin were generally synthesized by two methods: the first involves direct reaction of compound $\mathbf{2}$ with hydrazine hydrate to obtain compound $\mathbf{3}$, while the second involves the reaction of appropriate aromatic amine with the methyl iodide derivative of compound 2 .

\section{Synthesis of Compound 3}

Compound $\mathbf{3}$ was synthesized by direct addition of hydrazine hydrate to solution of compound $\mathbf{2}$ in warm ethanol following the procedure described by (Baker et al., 1954; 1952).

In a $100 \mathrm{~mL}$ flat bottomed flask, $(0.194 \mathrm{~g}, 0.5 \mathrm{mmol})$ of compound 2 was dissolved in $(10 \mathrm{~mL})$ warm ethanol followed by drop wise addition of $0.5 \mathrm{~mL}(10 \mathrm{mmol})$ hydrazine hydrate with stirring till the dark green color of the solution fade giving yellow-orange colored solution. Hydrogen sulfide $\left(\mathrm{H}_{2} \mathrm{~S}\right)$ started to liberate within 5 minutes after the amine addition. Half an hour later, hydrogen sulfide liberation ceased and cold water was added to the reaction mixture and kept in the refrigerator for $24 \mathrm{hrs}$. The precipitate of compound 3, 2(3', 4'-dimethoxyphenyl)-3, 5, 7-trimethoxy-4Hchromen-4-ylidene) hydrazine, was then collected.

\section{Synthesis of Compound 4}

Compound 4 was synthesized following the procedure described by (Baker et al., 1954; 1952). The reaction of compound 2 with methyl iodide takes place at room temperature.

In a $100 \mathrm{~mL}$ round flask a $(0.25 \mathrm{~g}, 0.64 \mathrm{mmol})$ of compound 2 was suspended in excess methyl iodide. The reaction mixture color changes from dark green to red. The precipitate was crystallized from the solution, collected after $24 \mathrm{hrs}$, then washed with ether to give compound 4, 2-(3',4'-dimethoxyphenyl)-3,5,7-trimethoxy4H-chromen-4-ylidene) methyl sulfonium iodide.

\section{Synthesis of Compound 5 and 6}

Compounds 5 and $\mathbf{6}$ were prepared from compound $\mathbf{4}$ by mild heating and stirring of the later in methanol with the suitable amine following the procedure described by (Baker et al., 1952).

\section{Synthesis of Compound 5}

In a $100 \mathrm{~mL}$ round bottomed flask, Aniline $(1 \mathrm{~mL}, 10$ mmol) was shaken with a suspension of compound $4(0.25$ $\mathrm{g}, 0.47 \mathrm{mmol}$ ) in $10 \mathrm{~mL}$ of warm ethanol. The reaction was completed in within $15 \mathrm{~min}$ with the liberation of methanethiol. The product was chromatographed through silica gel and dichloromethane: methanol (9:1) was used as an eluent. The dichloromethane: methanol portion was collected, rotary evaporated to give compound 5, 2-(3', 4'-dimethoxyphenyl)-3, 5, 7trimethoxy-N-phenyl-4H-chromen-4-imine.

\section{Synthesis of Compound 6}

In a $100 \mathrm{~mL}$ round flask $(0.75 \mathrm{~g}, 1.4 \mathrm{mmol})$ of compound 4 was suspended with $5 \mathrm{~mL}$ warm methanol and $0.75 \mathrm{~g}$ (4.09 mmol) of 3,4,5-trimethoxy aniline dissolved in $5 \mathrm{~mL}$ methanol was then added and the red color of the solution suddenly disappeared. The reaction accomplished within $3 \mathrm{hrs}$ to give yellow precipitate. The precipitate was washed with chloroform to give compound 6, 2-(3', 4'dimethoxyphenyl)-3,5,7-trimethoxy-N-(3", 4", 5"trimethoxyphenyl)-4H-chromen-4-imine.

\section{Physical Measurements}

Melting points were recorded in electrothermal melting point apparatus model Stuart SMP30 (UK) and were uncorrected. Elemental analysis was carried out on elementar Vario Microcube apparatus (Germany). IR spectra were recorded as $\mathrm{KBr}$ discs, using Stuart Shimadzu Corporation (Japan) spectrophotometer in the 
frequency range $4000-400 \mathrm{~cm}^{-1}$. UV-Visible spectra were recorded at compound concentration of $3 * 10-5 \mathrm{M}$ (in ethanol) using CECIL CE 7500 double beam UV/Visible spectrophotometer (England) $1 \mathrm{~cm}^{3}$ pathway quartz cells. 1HNMR spectra were recorded using Bruker $500 \mathrm{MHz}-$ avannce III and inova spectrometer at 400 and $500 \mathrm{MHz}$ using Tetramethyl Silane (TMS) as internal standard and, DMSO-d6 and $\mathrm{CDCl} 3$ as solvents. The chemical shifts being expressed in ppm and coupling constant in $\mathrm{Hz}$. The mass spectra of the studied compounds were obtained on a 5975C VL MSD with Tripe-Axis Detector (Agilent Technologies), using an ionizing potential of 70 $\mathrm{eV}$. The Electrospray Ionization (ESI) mass spectra were obtained with apex-iv detector using methanol and chloroform as solvents.

\section{Preliminary Cytotoxicity Screening}

Quercetin and its analogues 1-5 were screened for the preliminary in vitro anticancer activity against triple negative breast cancer MDA-MB-231 cell line by MTT (3-(4,5dimethylthiazo-2-yl)-2,5-diphenyltetrazolium bromide) colorimetric assay reported by (Mosmann, 1983) at department of zoology and cytology, Government college university, Faisalabad 38000, Pakistan. The cultured human breast cancer cells were treated with $0.1 \mathrm{mg} / \mathrm{mL}$ of Quercetin and its derivatives 1-5 solutions in DMSO and were tested in triplicate. Cancer cells treated with DMSO only were used as control. After incubation for $48 \mathrm{~h}$ at $37^{\circ} \mathrm{C}$ and $5 \% \mathrm{CO}_{2}$, the cells were washed with Phosphate Buffer Saline (PBS) to remove dead cells and cell debris and treated with $0.5 \mathrm{mg} / \mathrm{mL}$ MTT and further incubated for 4 hrs. at $37^{\circ} \mathrm{C}$ and $5 \% \mathrm{CO}_{2}$ till formazan crystals were form, these crystals were dissolved in DMSO and absorbance was measured at $570 \mathrm{~nm}$. The percentage of viable cells were then calculated according to Eq. 1:

$$
\mathrm{V}=\left(\left(\mathrm{A}_{\text {sample }}-\mathrm{A}_{\text {control }}\right) / \mathrm{A}_{\text {control }}\right) \times 100 \%
$$

Where:

$\mathrm{V}=$ The percentage of cancer cells remaining viable after being treated with anticancer agent $(\%)$

$\mathrm{A}_{\text {sample }}=$ The absorbance of the tested compound

$\mathrm{A}_{\text {control }}=$ The absorbance of the positive control (i.e.; untreated cells)

When the sample absorbance values greater than the control this indicate cell proliferation, while lower values suggest cell death.

\section{Calculation of the $I C_{50}$ Value of the Active Compounds}

This step involve $\mathrm{IC}_{50}$ determination for the compounds that have shown good anticancer activity against MDA-MB231 cell line from previous step by studying the effect of various concentrations $(1,2,4$, $8,15.6,31.25,62.5,125,250,500 \mu \mathrm{M})$ of these compounds on the viability of breast cancer cells and evaluating their effect using MTT assay. The results were analyzed and the $\mathrm{IC}_{50}$ values were calculated using Graph Pad Prism 8.1 program and the results were expressed as \pm SEM, with $\mathrm{p}$ value $<0.05$.

\section{Molecular Docking Studies}

In this study Jaunas kinase-2 (JAK2) was used because it is the target to produce the response of many anticancer drugs (Abu Bakar et al., 2018). In the docking study the crystal structure of JAK2 cocrystallized with a potent quinoxaline inhibitor, PDB: 3KRR, was downloaded. In order to investigate the reaction of quercetin and its 1-6 analogues against the targeted proteins a docking study was undertaken between the studied molecules and the JAK2 protein. Docking is a strong computational method for predicting the position of the ligand within the active site of the protein, which reveals the amino acids that interact with binding ligand. This offers valuable information about how the drug positioned within the active site and the coordinates between the different interacted groups.

Molecular Operating System (MOE) docking program was used in this study. As a starting step, the structures of the studied molecules were optimized and prepared for docking using the program SYBYL-X. The structure of the targeted protein is also repaired for the missing parts and for adding missing protons using the same program. The docking calculations will determine the position of the ligand within the active site of the protein as well as calculating the affinity of the ligand to the protein which could be taken as biological activity of the ligand. The binding mode is the top 1 hitting. The MOE program calculates the binding free energy as the affinity between the protein and the ligand. In this program the binding free energy for the ligand is called the score and abbreviated as $\mathrm{S}$ and in this case the largest negative value of $\mathrm{S}$ means the highest affinity and accordingly the highest biological activity.

\section{Results}

The physical properties and UV-visible spectral data of Quercetin and its 1-6 analogues are shown in Table 1, while mass spectra and elemental analysis data are gathered in Table 2 and the IR and the ${ }^{1}$ HNMR spectral data are gathered in Tables 3 and 4 respectively.

In vitro antiproliferative activity results of Quercetin and five of its analogues (1-5) against breast cancer 
MDA-MB-231 cell line showed that Quercetin and compound 5 were inactive, while compound 1-4 shows a good activity and gave a great reduction in the percentage of cell viability, additionally, the $\mathrm{IC}_{50}$ value for the most active compound ( $\mathbf{1}$ and $\mathbf{4}$ ) were calculated and as shown in Table 5.

Theoretically the antiproiferative activities were estimated using Molecular docking assay against Jaunas kinase-2 (JAK2) protein (PDB: 3KRR) for Quercetin and its analogues (1-5) and the results were expressed along with the experimental results in Table 6. Structures of the studied molecules are shown in Fig. 3-9. The correlation between the calculated binding free energies with the experimental biological activities of the studied molecules is shown in Fig. 10. The predicted binding sites of the studied compounds within the target protein are shown in Fig. 11-22 and Table 7.

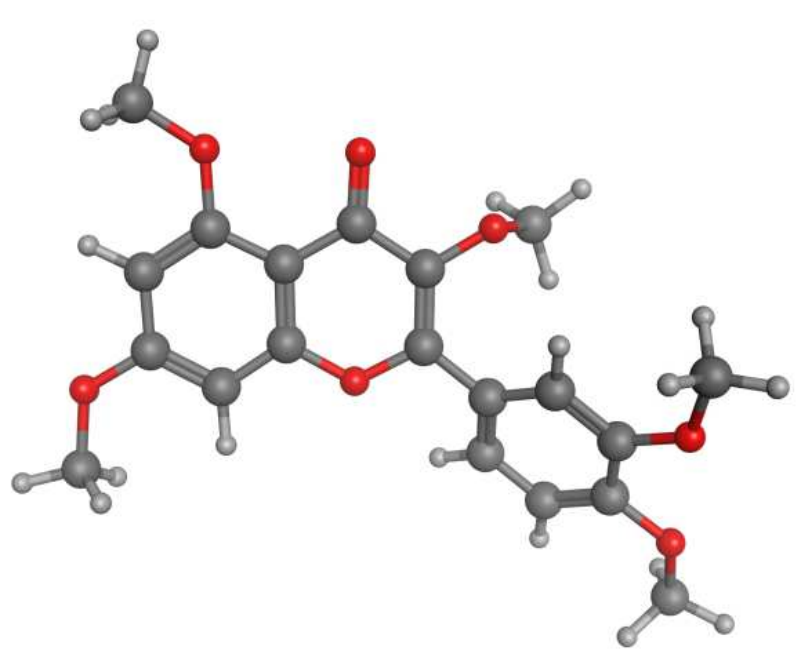

Fig. 3: The molecular structure of compound 1

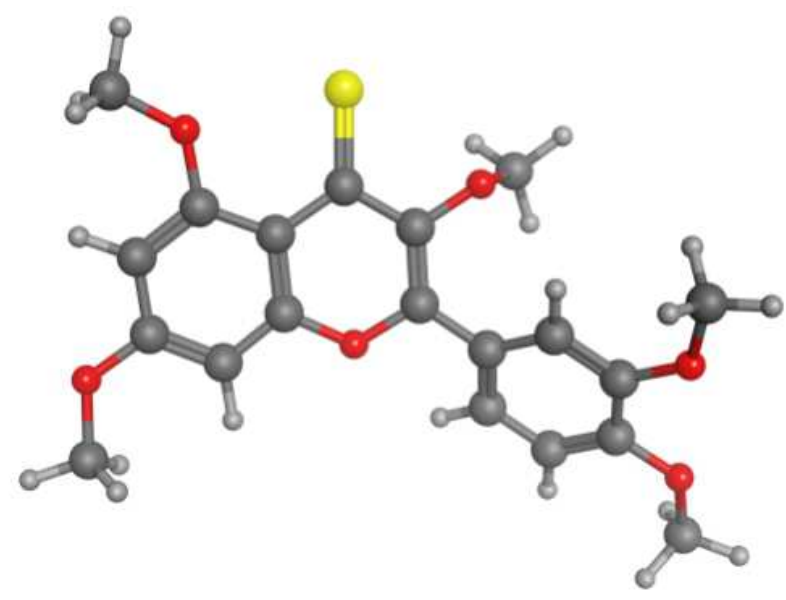

Fig. 4: The molecular structure of compound 2

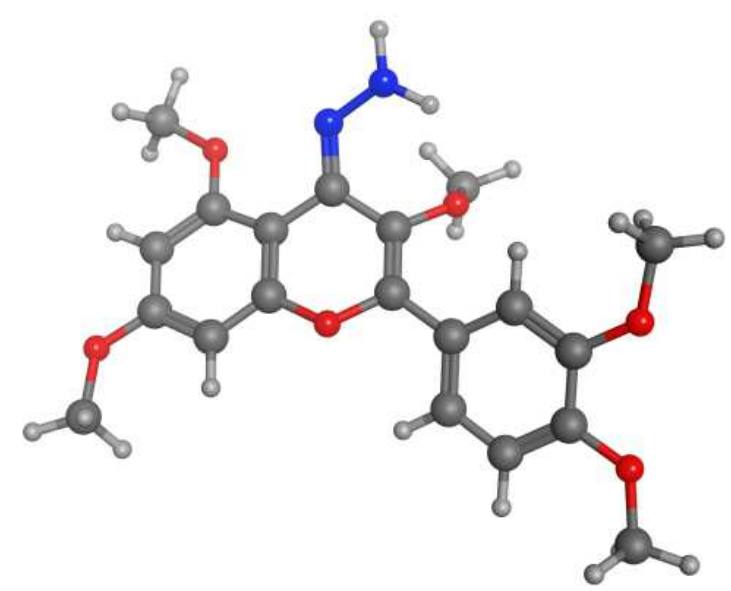

Fig. 5: The molecular structure of compound 3

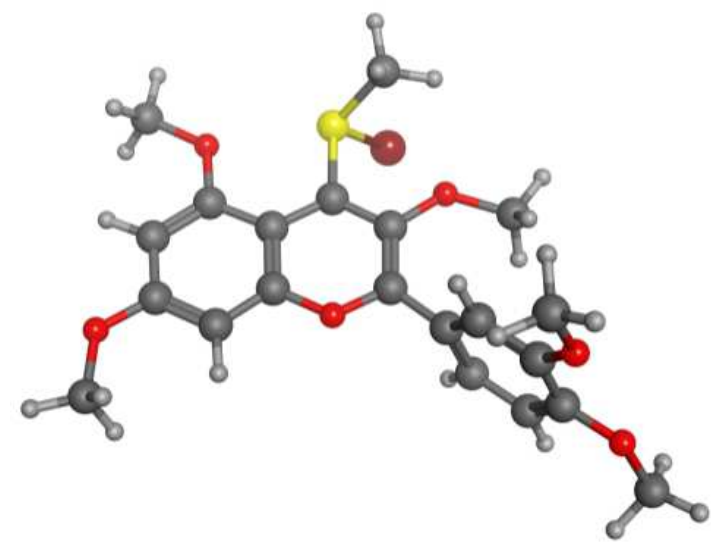

Fig. 6: the molecular structure of compound 4

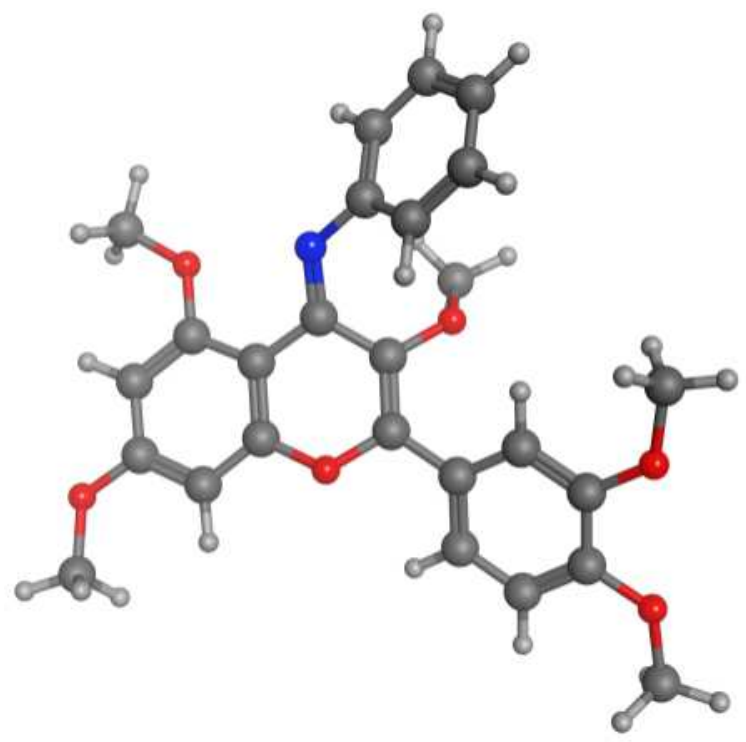

Fig. 7: The molecular structure of compound 5 


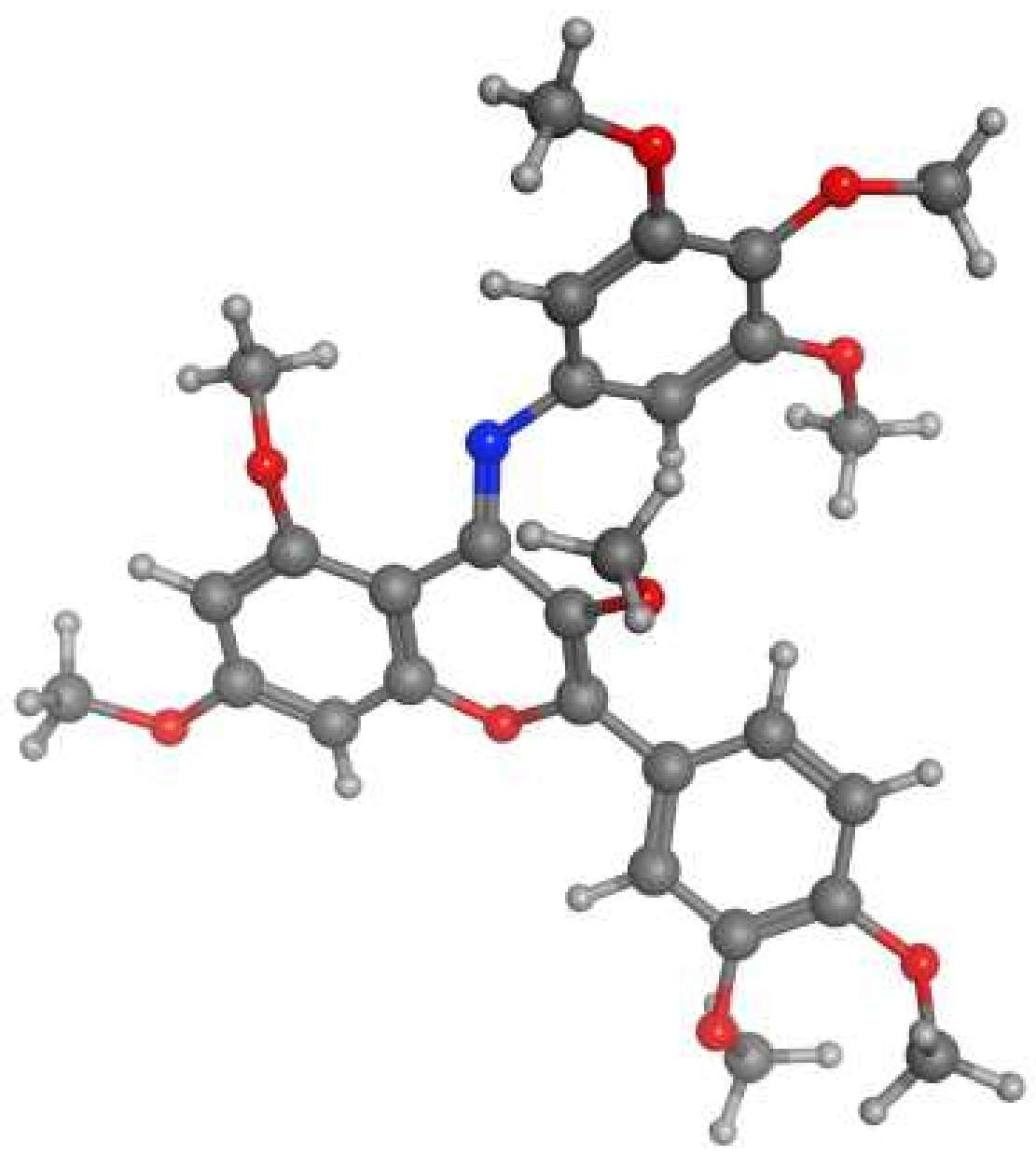

Fig. 8: The molecular structure of compound 6

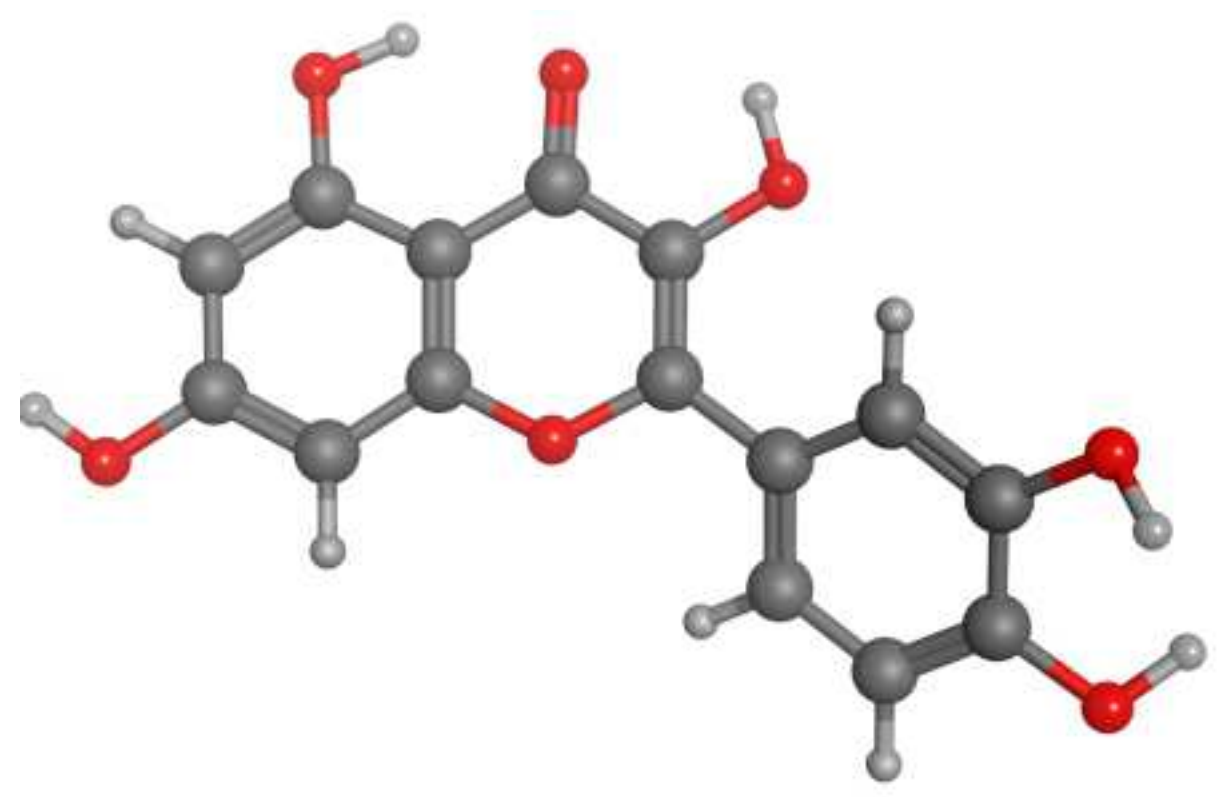

Fig. 9: the molecular structure of Quercetin 


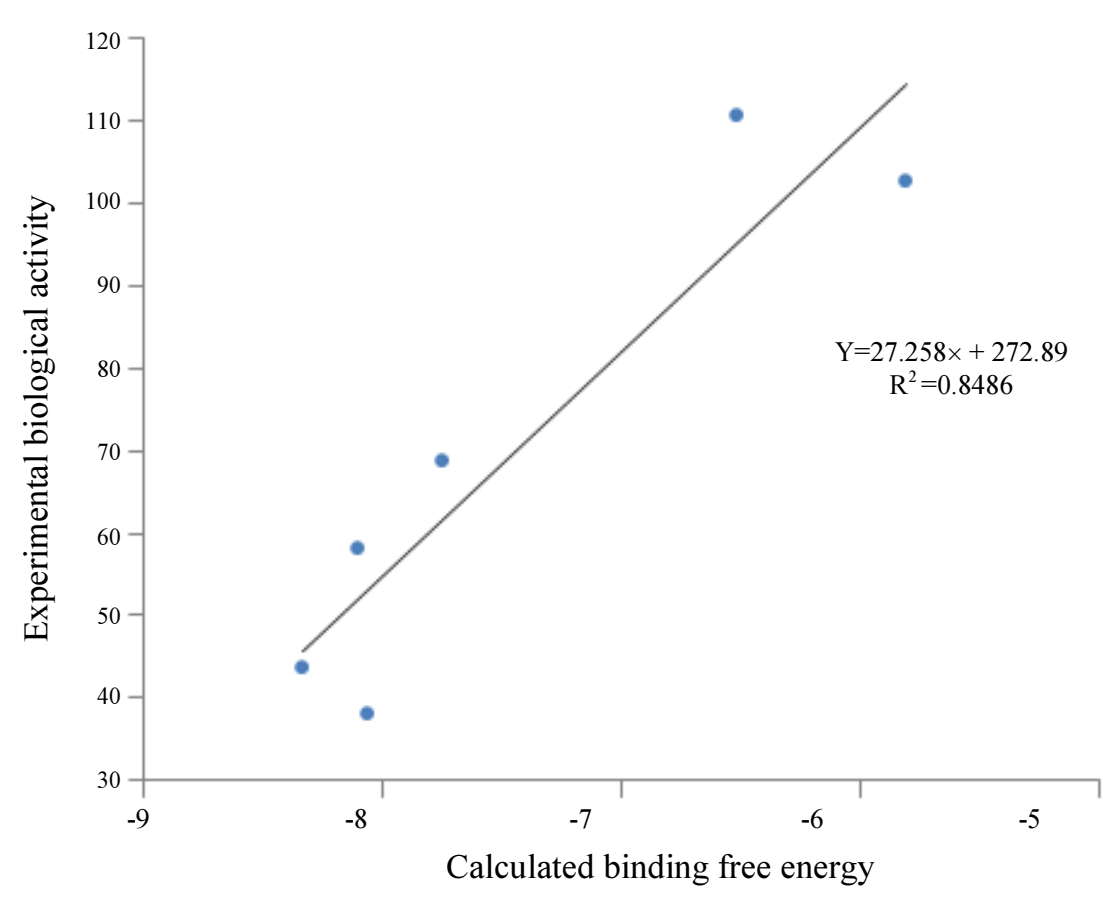

Fig. 10: The calculated binding free energies vs the experimental biological activities of the studied molecules

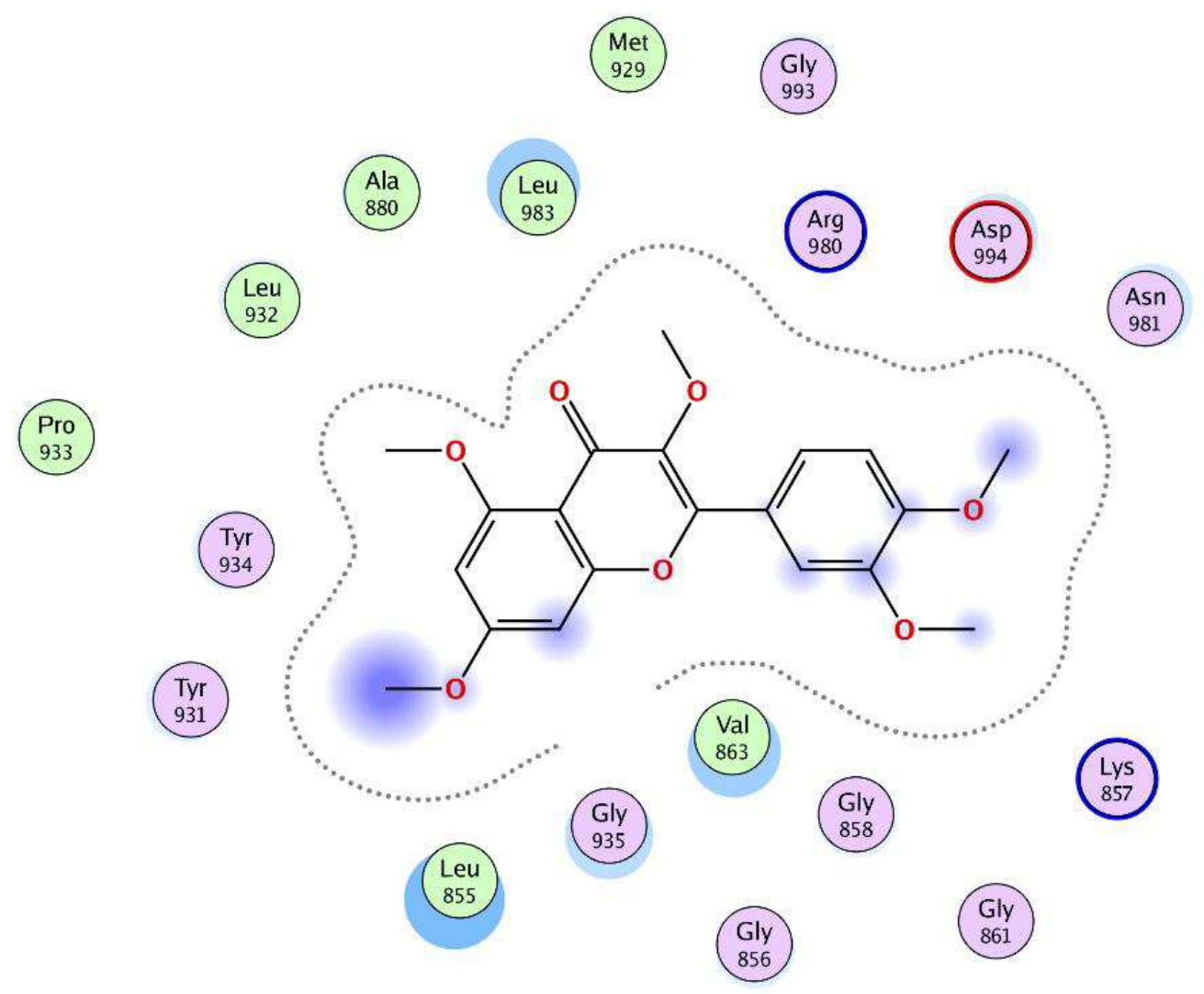

Fig. 11: Ligand interactions of compound 1 with the target protein 


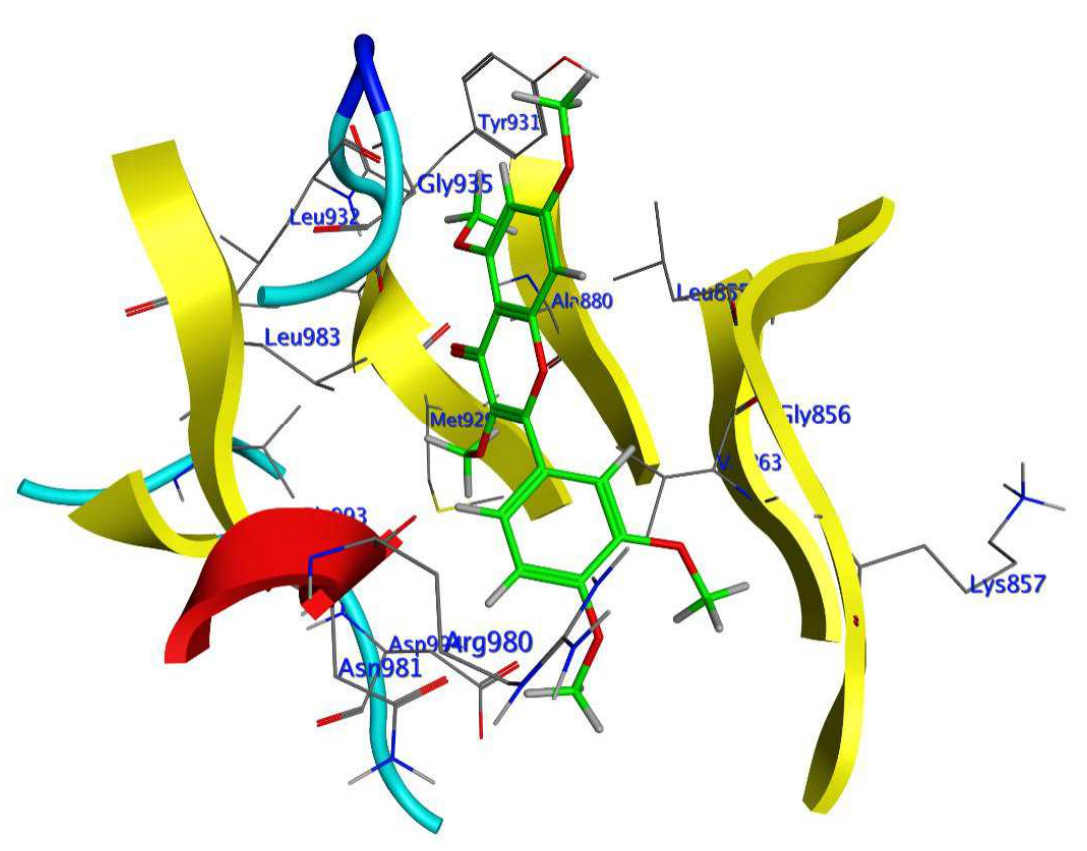

Fig. 12: The active site of compound 1 in the target protein

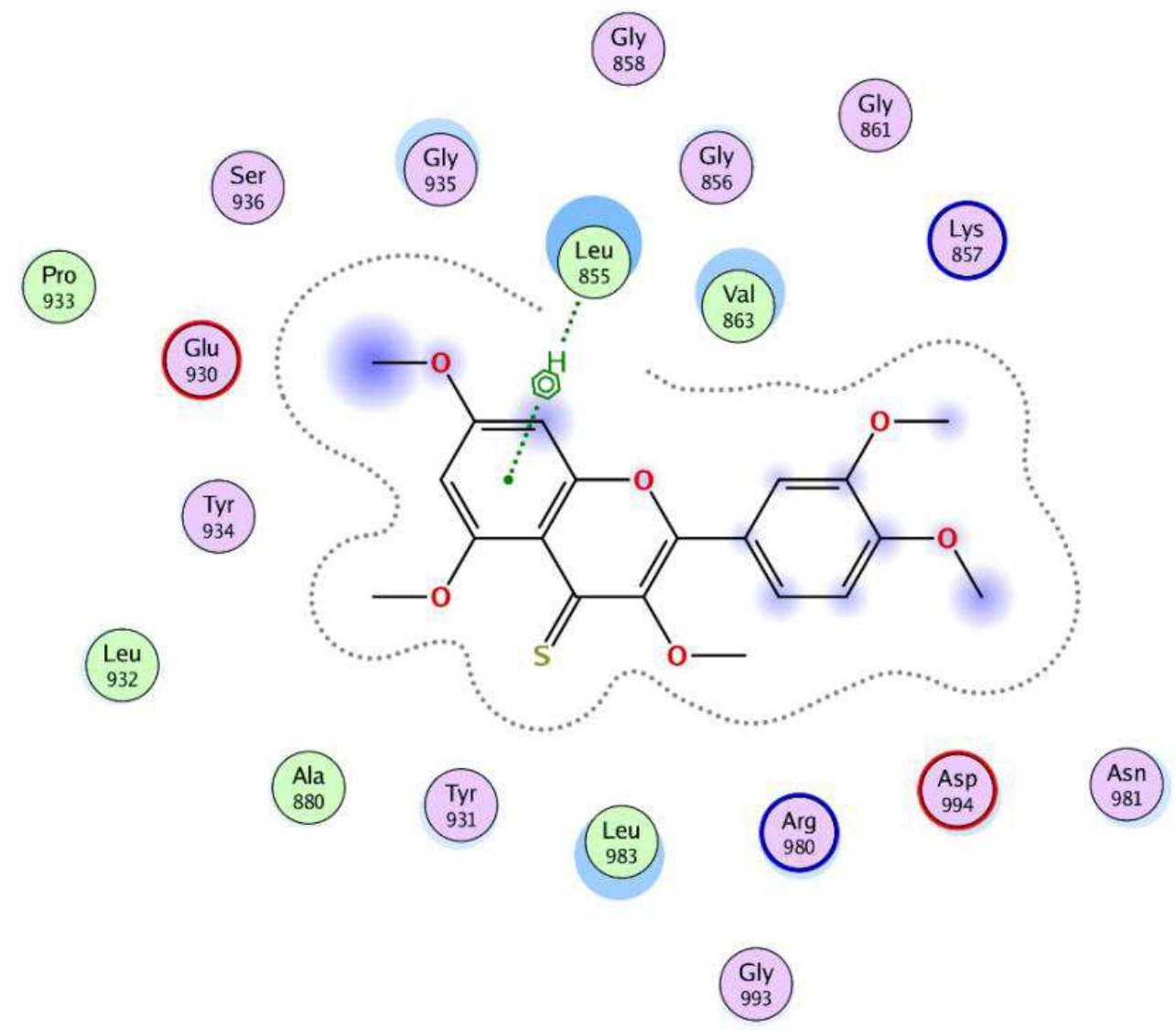

Fig. 13: Ligand interactions of compound 2 with the target protein 


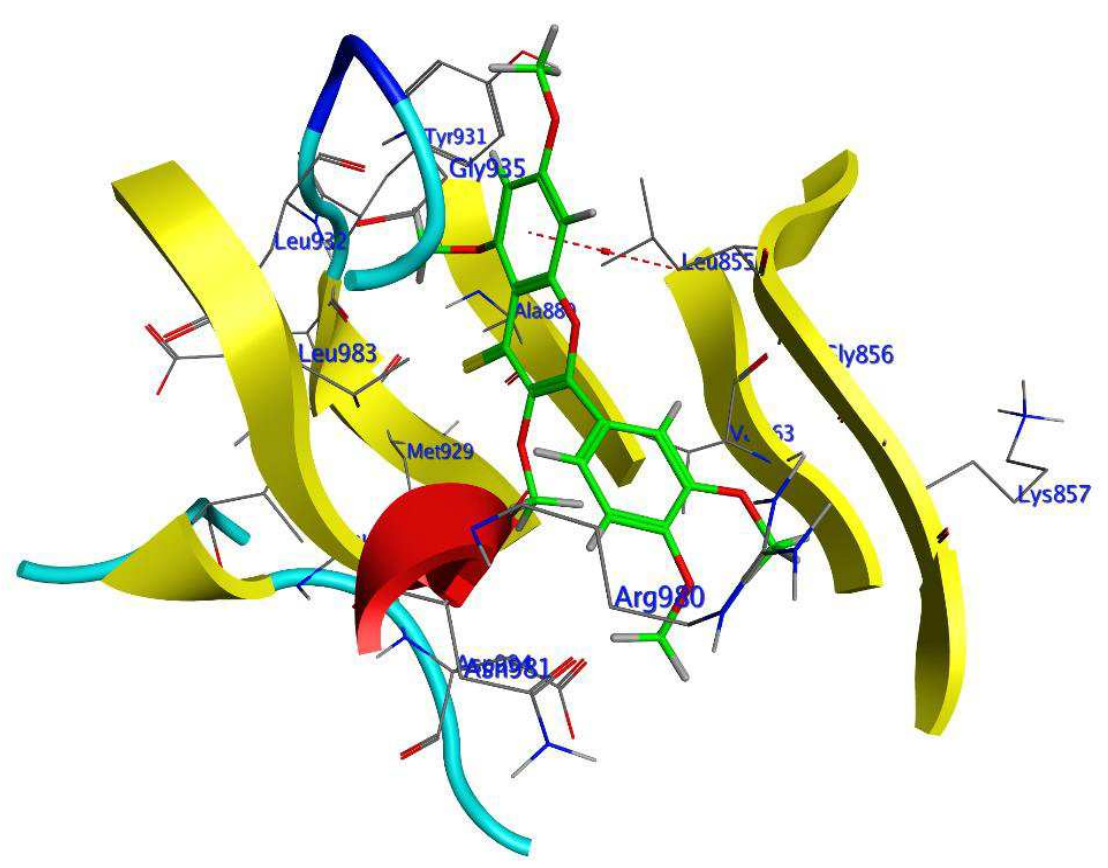

Fig. 14: The active site of compound 2 in the target protein

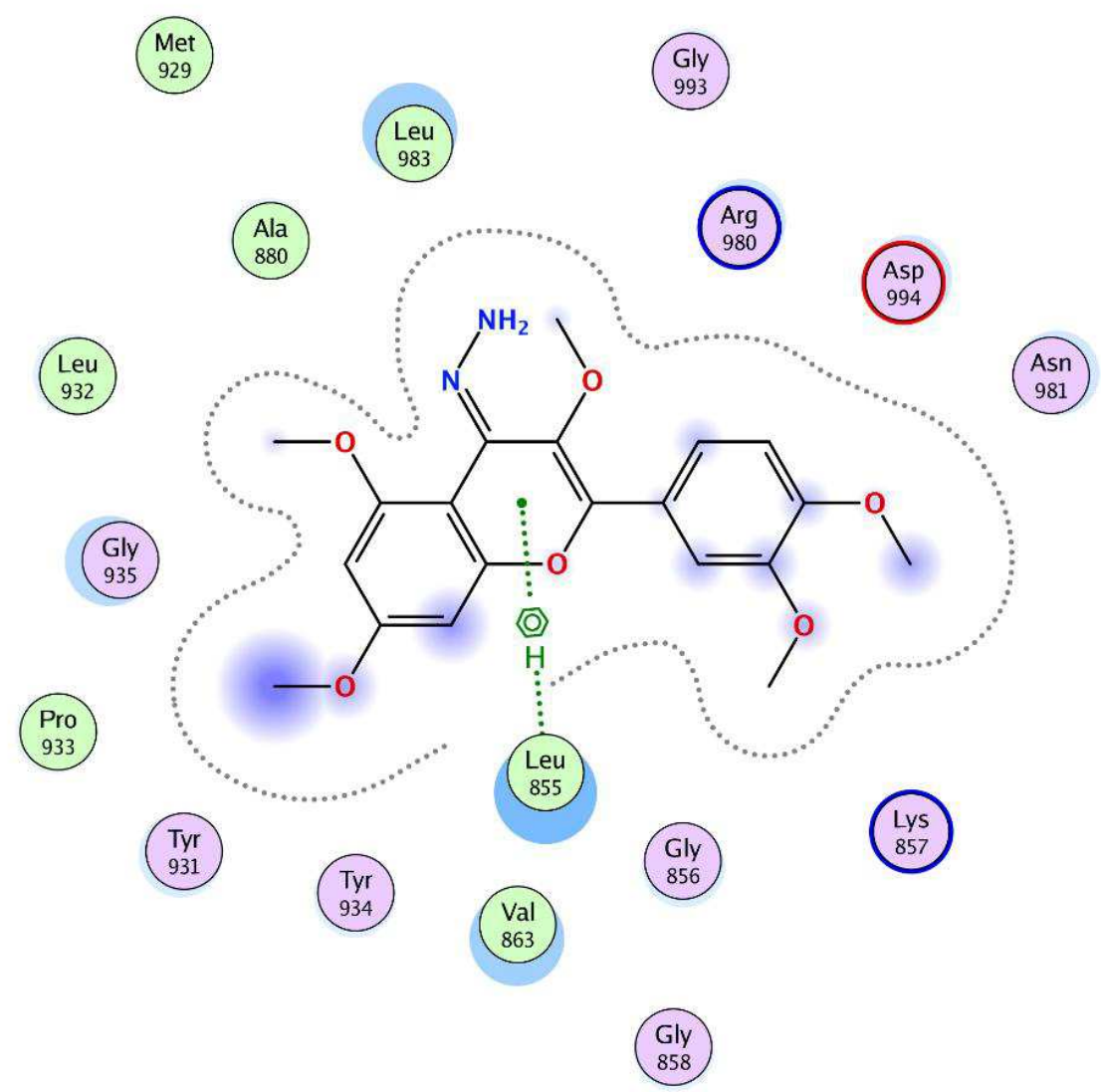

Fig. 15: Ligand interactions of compound 3 with the target protein 


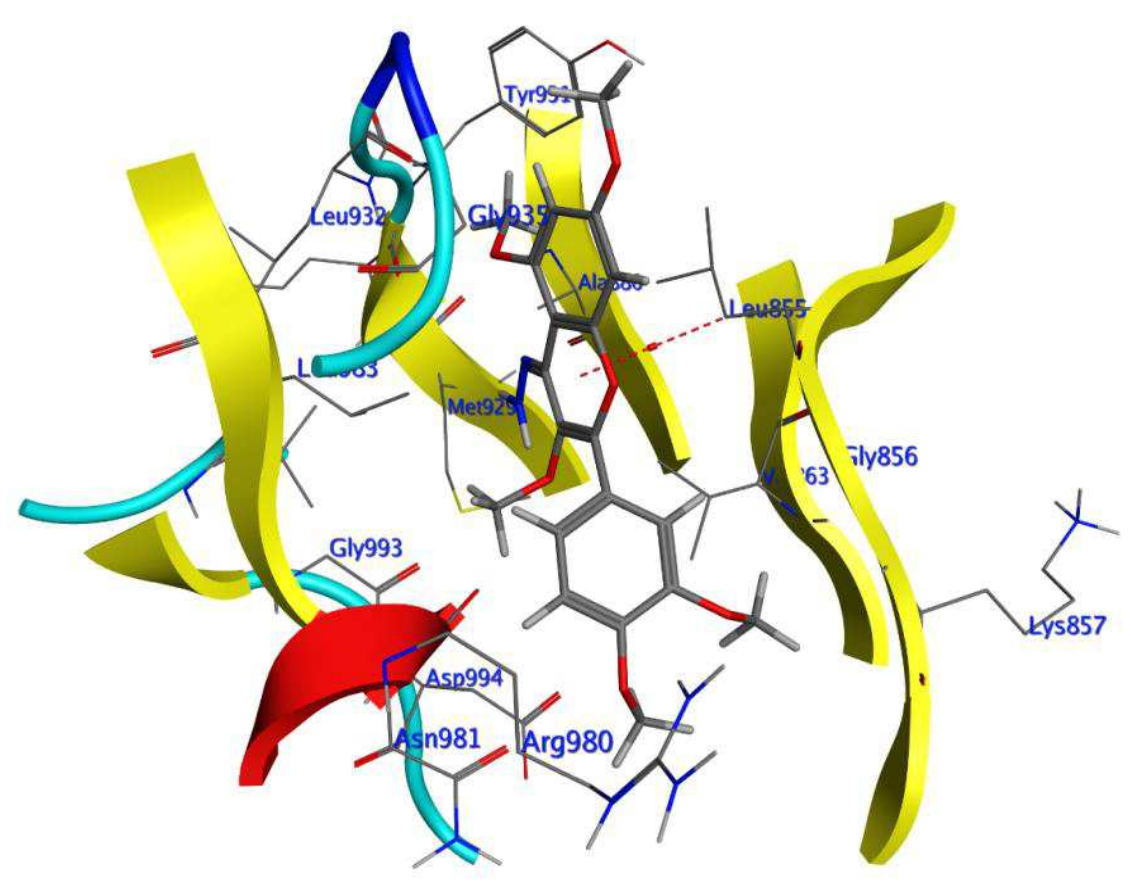

Fig. 16: the active site of compound 3 in the target protein

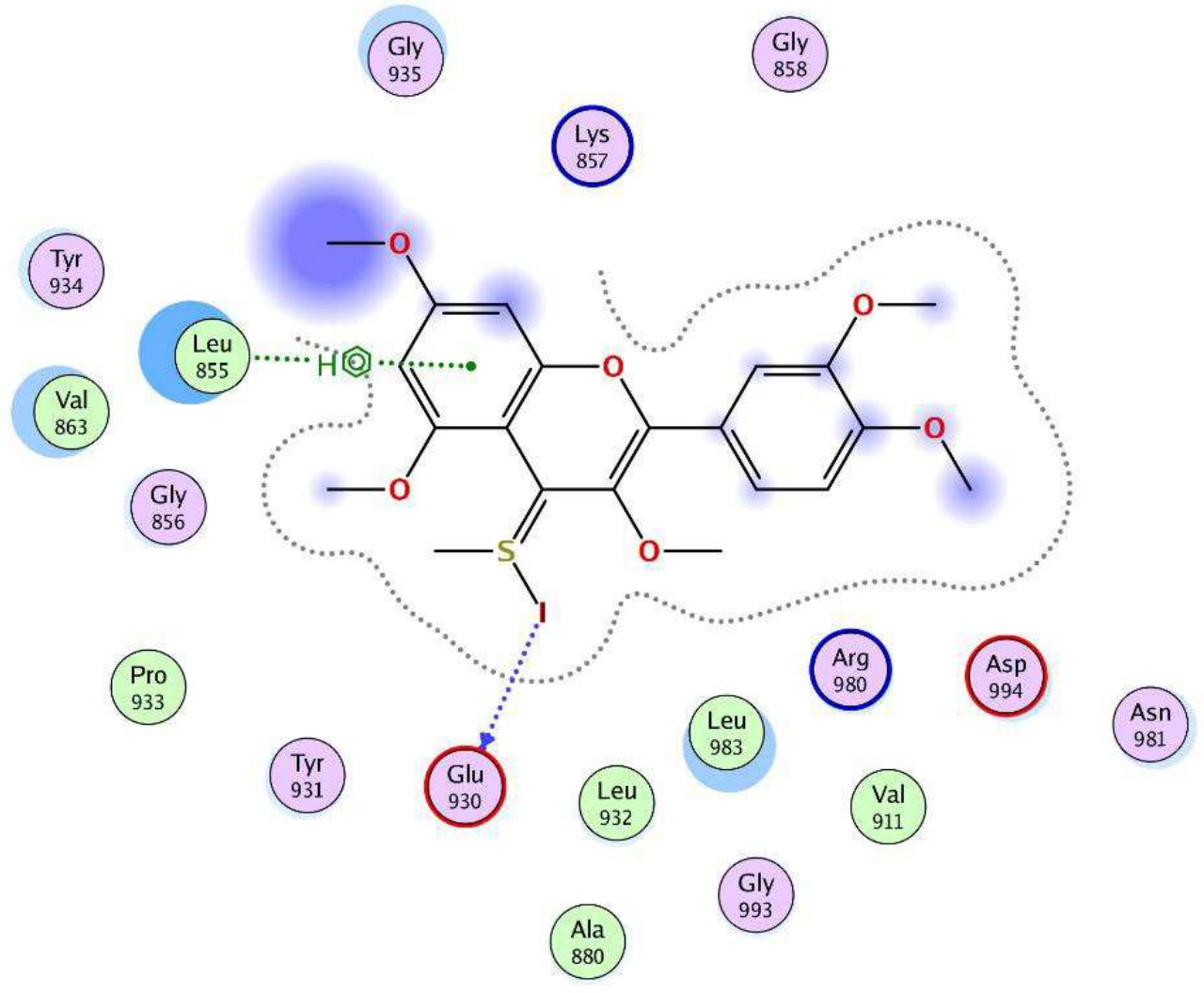

Fig. 17: Ligand interactions of compound 4 with the target 


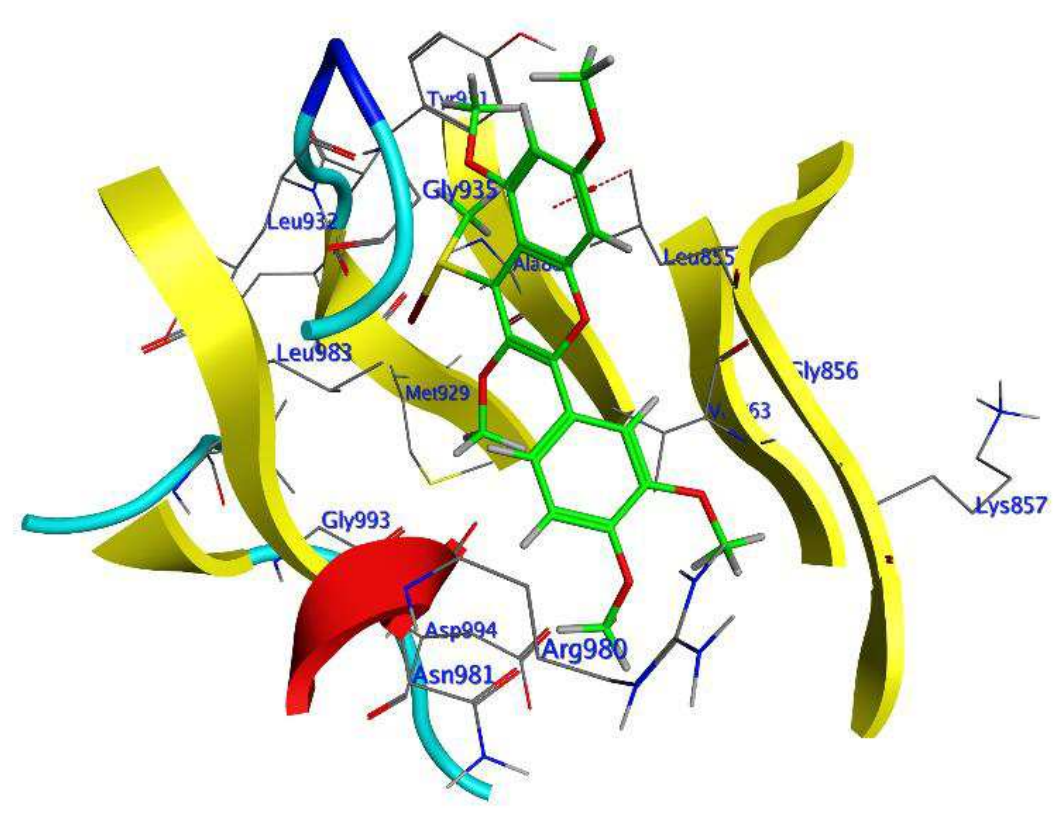

Fig. 18: The active site of compound 4 in the target protein

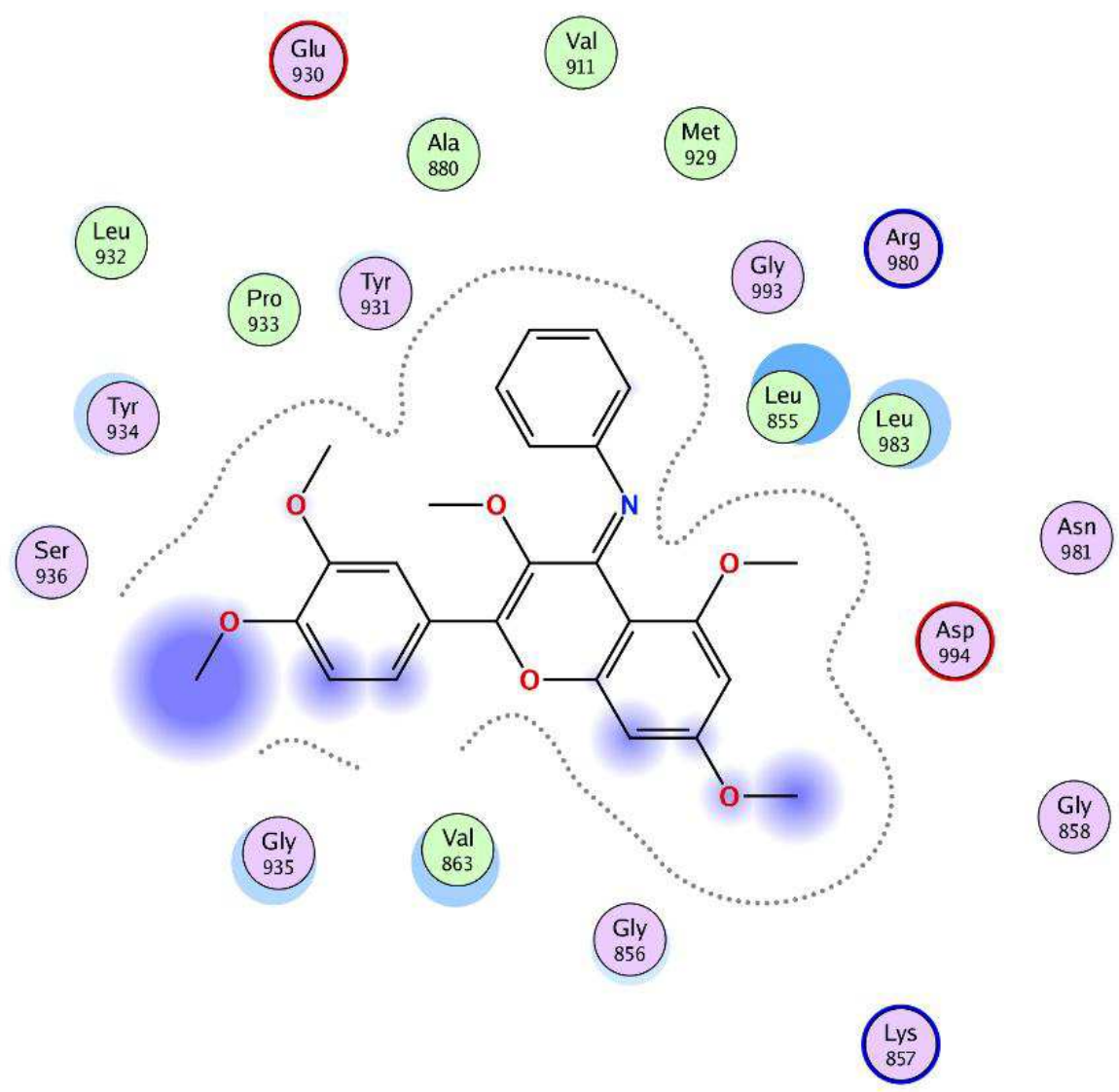

Fig. 19: Ligand interactions of compound 5 with the target protein 


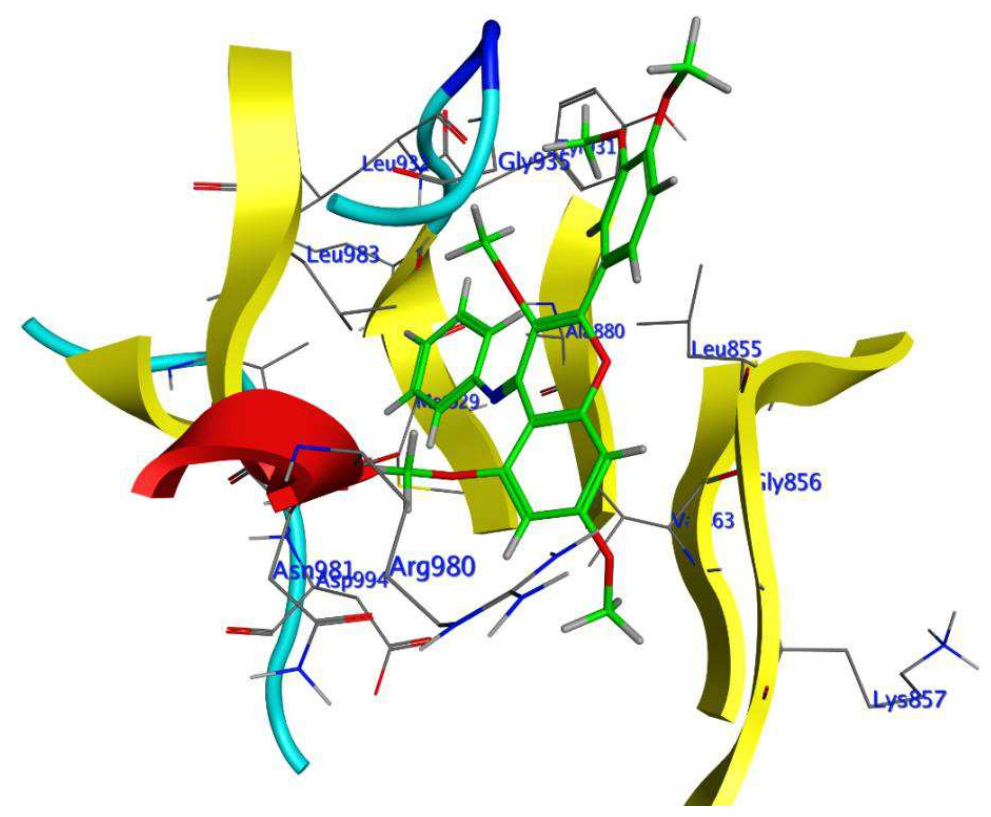

Fig. 20: The active site of compound 5 in the target protein

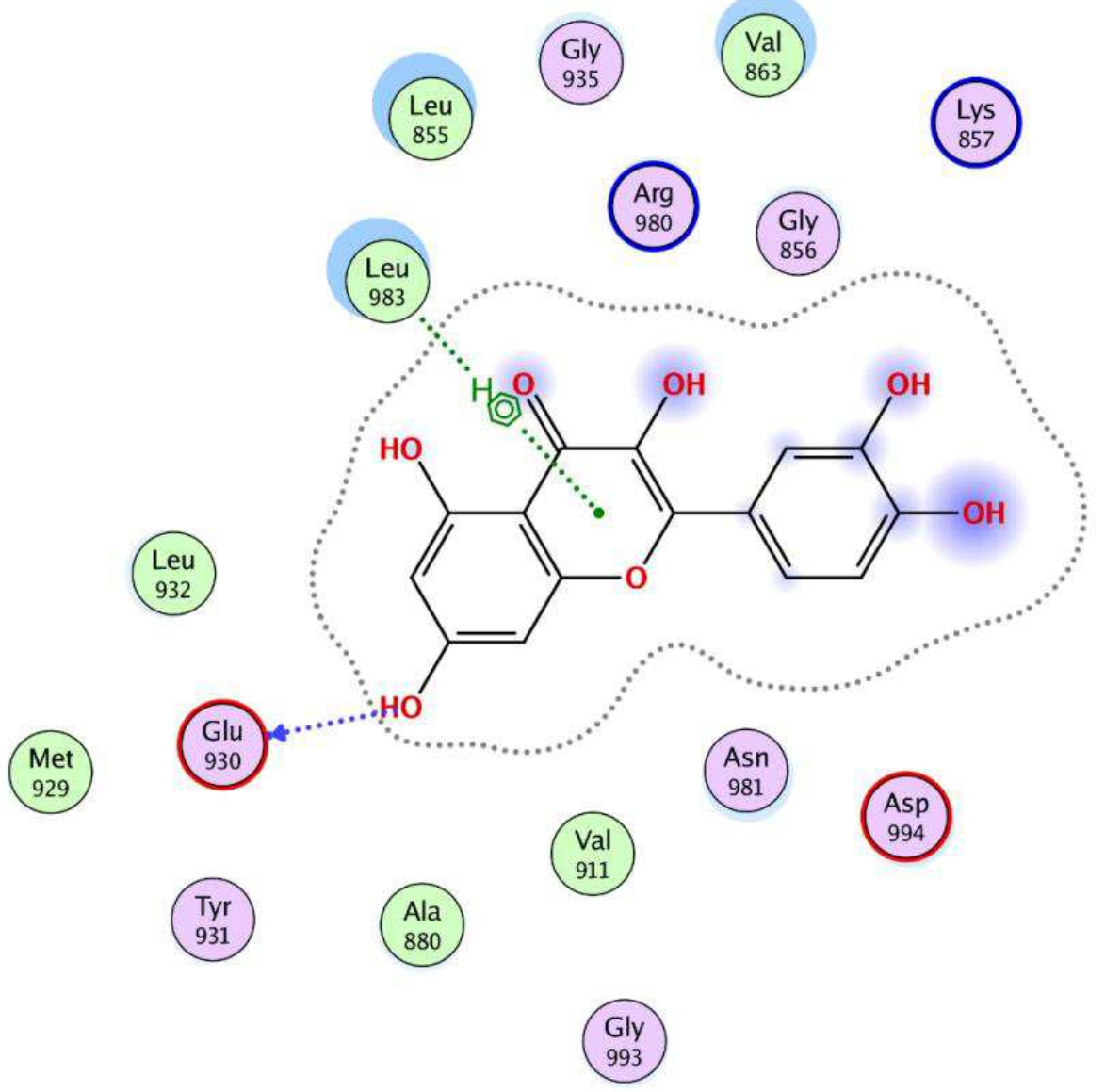

Fig. 21: Ligand interactions of Quercetin with the target protein 


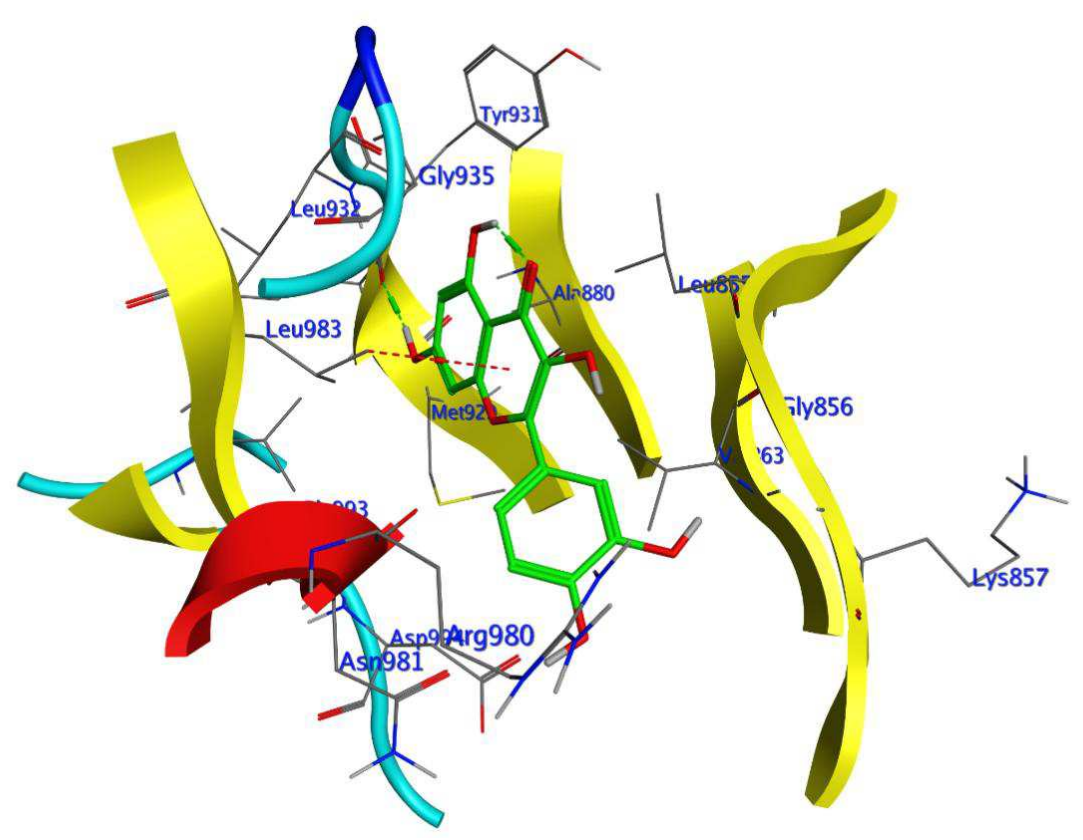

Fig. 22: The active site of Quercetin in the target protein

Table 1: Physical properties and UV-visible spectra of Quercetin and its 1-6 analogues

\begin{tabular}{|c|c|c|c|c|}
\hline Compounds & Color & Yield \% & Melting point ${ }^{\circ} \mathrm{C}$ & $\lambda \max \mathrm{nm}$ \\
\hline Quercetin & yellow & - & $314.0-315.0$ & $\begin{array}{l}372.0 \\
257.0\end{array}$ \\
\hline 1 & white & 70 & $150.0-151.0$ & $\begin{array}{l}339.5 \\
248.0\end{array}$ \\
\hline 2 & dark green & 39 & $169.2-170.2$ & $\begin{array}{l}397.5 \\
262.5\end{array}$ \\
\hline 3 & orange & 60 & $163.0-164.0$ & $\begin{array}{l}323.5 \\
289.5\end{array}$ \\
\hline 4 & dark red & 78 & $156.4-157.4$ & $\begin{array}{l}335.5 \\
265.5\end{array}$ \\
\hline 5 & yellow & 63 & $126.0-128.0$ & $\begin{array}{l}404.5 \\
265.0\end{array}$ \\
\hline 6 & yellow & 50 & $149.8-150.1$ & $\begin{array}{l}401.0 \\
265.5\end{array}$ \\
\hline
\end{tabular}

Table 2: Mass spectra and elemental analysis of Quercetin and its 1-6 analogues

\begin{tabular}{|c|c|c|c|c|c|}
\hline Compounds & $\begin{array}{l}\text { Molecular weights } \\
(\mathrm{g} / \text { mole })\end{array}$ & $\begin{array}{l}\text { Mass } \\
\left(\mathrm{M}^{+}\right) \mathrm{m} / \mathrm{e}\end{array}$ & $\begin{array}{l}\text { Mass } \\
\left(\mathrm{M}+\mathrm{H}^{+}\right) \mathrm{m} / \mathrm{e}\end{array}$ & $\begin{array}{l}\text { CHNS\% } \\
\text { Found }\end{array}$ & $\begin{array}{l}\text { CHNS\% } \\
\text { Calculated }\end{array}$ \\
\hline Quercetin & 302.40 & $302^{\mathrm{a}}$ & - & - & - \\
\hline 1 & 372.00 & 372.0 & - & - & - \\
\hline \multirow[t]{2}{*}{2} & 388.10 & 388.0 & - & C: 60.69 & C: 61.84 \\
\hline & & & & $\begin{array}{l}\text { H: } 4.958 \\
\text { S: } 9.157\end{array}$ & $\begin{array}{l}\text { H: } 5.19 \\
\text { S: } 8.25\end{array}$ \\
\hline \multirow[t]{3}{*}{3} & 386.15 & 386.6 & 387.15 & C: 62.50 & C: 62.17 \\
\hline & & & & H: 5.511 & H: 5.74 \\
\hline & & & & N: 6.68 & $\mathrm{~N}: 7.25$ \\
\hline \multirow[t]{3}{*}{4} & 530.00 & - & - & $C: 46.73$ & $C: 47.56$ \\
\hline & & & & H: 4.38 & H: 4.37 \\
\hline & & & & S: 5.78 & S: 6.04 \\
\hline 5 & 447.10 & 447.3 & 448.17 & - & - \\
\hline 6 & 537.20 & 537.0 & - & - & - \\
\hline
\end{tabular}

a as previously reported by (Ice and Wender, 1953) 
Table 3: The IR spectra data of the most important absorption bands for Quercetin and its analogues (1-6)

\begin{tabular}{|c|c|c|c|c|c|c|c|}
\hline Compounds & $\begin{array}{l}\mathrm{OH} \\
\text { stretching }\end{array}$ & $\begin{array}{l}\mathrm{NH}_{2} \\
\text { stretching }\end{array}$ & $\begin{array}{l}\mathrm{C}=\mathrm{O} \\
\text { stretching }\end{array}$ & $\begin{array}{l}\mathrm{C}=\mathrm{S} \\
\text { stretching }\end{array}$ & $\begin{array}{l}\mathrm{C}=\mathrm{N} \\
\text { stretching }\end{array}$ & $\begin{array}{l}\mathrm{C}=\mathrm{C} \\
\text { stretching }\end{array}$ & $\begin{array}{l}\mathrm{C}-\mathrm{H} \\
\text { aliphatic }\end{array}$ \\
\hline Quercetin & $\begin{array}{l}3437-1800 \\
w, \text { br }\end{array}$ & - & $1666 \mathrm{~s}$ & - & - & $\begin{array}{l}1612 \mathrm{vs} \\
1562 \mathrm{~s} \\
1523 \mathrm{vs}\end{array}$ & - \\
\hline 1 & - & - & $1627 \mathrm{vs}$ & - & - & $\begin{array}{l}1604(\mathrm{sh}) \mathrm{vs} \\
1516 \mathrm{~s} \\
1496(\mathrm{sh}) \mathrm{vs}\end{array}$ & $\begin{array}{l}2993 \\
2947 \\
2931 \\
2843\end{array}$ \\
\hline 2 & - & - & - & $1253 \mathrm{~s}$ & - & $\begin{array}{l}1620(\mathrm{sh}) \mathrm{vs} \\
1589(\mathrm{sh}) \mathrm{vs} \\
1519 \mathrm{~s}\end{array}$ & $\begin{array}{l}2993 \\
2947 \\
2931 \\
2843\end{array}$ \\
\hline 3 & - & $\begin{array}{l}3417 \mathrm{~m} \\
3387 \mathrm{~m}\end{array}$ & - & - & $1635 \mathrm{~s}$ & $\begin{array}{l}1600(\mathrm{sh}) \mathrm{s} \\
1585(\mathrm{sh}) \mathrm{s} \\
1516 \mathrm{~s}\end{array}$ & $\begin{array}{l}2935 \\
2835\end{array}$ \\
\hline 4 & - & - & - & $1260 \mathrm{~s}$ & - & $\begin{array}{l}1627 \mathrm{vs} \\
1573(\mathrm{sh}) \mathrm{m} \\
1481 \mathrm{~s}\end{array}$ & $\begin{array}{l}2981 \\
2935\end{array}$ \\
\hline 5 & - & - & - & - & $1631 \mathrm{~s}$ & $\begin{array}{l}1593 \mathrm{~s} \\
1554 \mathrm{~s} \\
1504\end{array}$ & $\begin{array}{l}2935 \\
2839\end{array}$ \\
\hline 6 & - & - & - & - & $1631 \mathrm{~s}$ & $\begin{array}{l}1593 \mathrm{~s} \\
1573 \mathrm{~s} \\
1500 \mathrm{~s}\end{array}$ & $\begin{array}{l}2839 \\
2939 \\
3001\end{array}$ \\
\hline
\end{tabular}

Vs: very strong, S: strong, m: medium, w: weak, br: broad, sh: shoulder, str: stretching<smiles>C=C1C(OC)=C(c2ccc(OC)c(OC)c2)Oc2cc(OC)cc(OC)c21</smiles>

Table 4: ${ }^{1} \mathrm{HNMR}$ spectra of the Quercetin and its 1-6 analogues

\begin{tabular}{|c|c|c|c|c|c|c|c|c|}
\hline Compounds & $\begin{array}{l}\text { Phenolic } \\
\mathrm{OH}\end{array}$ & H6 & $\mathrm{H} 8$ & $\mathrm{H} 2^{\prime}$ & $\mathrm{H} 5^{\prime}$ & H6' & $\mathrm{OCH} 3$ & R-substituent \\
\hline Quercetin & $\begin{array}{l}9.25, \text { br s } \\
(3 \mathrm{H}) \\
10.62, \text { br s } \\
(1 \mathrm{H}) \\
12.42, \mathrm{~s} \\
(1 \mathrm{H})\end{array}$ & $6.14 \mathrm{~s}$ & $6.35 \mathrm{~s}$ & $\begin{array}{l}7.63 \mathrm{~d} \\
\mathrm{~J}_{\mathrm{m}}=1.5\end{array}$ & $\begin{array}{l}7.87 \mathrm{~d} \\
\mathrm{~J}_{\mathrm{o}}=8.4\end{array}$ & $\begin{array}{l}7.49 \mathrm{dd} \\
\mathrm{J}_{\mathrm{o}, \mathrm{m}}=8.4, .5\end{array}$ & - & - \\
\hline 1 & & $\begin{array}{l}6.45 \mathrm{~d} \\
\mathrm{~J}_{\mathrm{m}}=1.8\end{array}$ & $\begin{array}{l}6.77 \mathrm{~d} \\
\mathrm{~J}_{\mathrm{m}}=1.8\end{array}$ & $7.62 \mathrm{~s}$ & $\begin{array}{l}7.11 \mathrm{~d} \\
\mathrm{~J}_{\mathrm{o}}=8.6\end{array}$ & $\begin{array}{l}7.65 \mathrm{dd} \\
\mathrm{J}_{\mathrm{o}, \mathrm{m}}=8.6,1.6\end{array}$ & $3.70-3.87 \mathrm{~m}$ & \\
\hline 2 & & $6.42 \mathrm{~s}$ & $6.53 \mathrm{~s}$ & $7.86 \mathrm{~s}$ & $\begin{array}{l}6.99 \mathrm{~d} \\
\mathrm{~J}_{\mathrm{O}}=8.5\end{array}$ & $\begin{array}{l}7.77 \mathrm{~d} \\
\mathrm{~J}_{\mathrm{o}}=8.5\end{array}$ & $3.70-3.97 \mathrm{~m}$ & \\
\hline 3 & & $\begin{array}{l}6.33 \mathrm{~d} \\
\mathrm{~J}_{\mathrm{m}}=1.6\end{array}$ & $\begin{array}{l}6.46 \mathrm{~d} \\
\mathrm{~J}_{\mathrm{m}}=1.8\end{array}$ & $7.44 \mathrm{~s}$ & $\begin{array}{l}7.0 \mathrm{~d} \\
\mathrm{~J}_{\mathrm{o}}=9\end{array}$ & $7.44 \mathrm{~s}$ & $3.51-3.83 \mathrm{~m}$ & $\begin{array}{l}6.9 \mathrm{br}, \mathrm{s} \\
\left(\mathrm{NH}_{2}\right)\end{array}$ \\
\hline 4 & & $5.76 \mathrm{~s}$ & $5.79 \mathrm{~s}$ & $7.08 \mathrm{~s}$ & $\begin{array}{l}6.82 \mathrm{~d} \\
\mathrm{~J}_{\mathrm{o}}=8.4\end{array}$ & $\begin{array}{l}7.27 \mathrm{~d} \\
\mathrm{~J}_{\mathrm{O}}=8.4\end{array}$ & $3.44-3.73 \mathrm{~m}$ & $\begin{array}{l}1.68 \mathrm{~s} \\
\left(\mathrm{~S}-\mathrm{CH}_{3}\right)\end{array}$ \\
\hline 5 & & $6.37 \mathrm{~s}$ & $6.76 \mathrm{~s}$ & $7.52 \mathrm{~s}$ & $\begin{array}{l}7.09 \mathrm{~d} \\
\mathrm{~J}_{\mathrm{o}}=8.6\end{array}$ & $\begin{array}{l}7.6 \mathrm{~d} \\
\mathrm{~J}_{\mathrm{o}}=8.4\end{array}$ & $3.7-3.83 \mathrm{~m}$ & $7.14-7.35 \mathrm{~m}$ \\
\hline 6 & & $7.07 \mathrm{~s}$ & $7.46 \mathrm{~s}$ & $7.78 \mathrm{~s}$ & $\begin{array}{l}7.34 \mathrm{~d} \\
\mathrm{~J}_{\mathrm{o}}=8.8\end{array}$ & $\begin{array}{l}7.96 \mathrm{~d} \\
\mathrm{~J}_{\mathrm{o}}=8.4\end{array}$ & $3.25-4.26 \mathrm{~m}$ & $7.07 \mathrm{~s}$ \\
\hline
\end{tabular}


Table 5: Percentage of breast cancer cell line MDA-MB231 cells that remain viable after being treated with Quercetin and its analogues under appropriate conditions

\begin{tabular}{|c|c|c|c|c|c|}
\hline Compounds & $\begin{array}{l}\text { viable cells } \% \\
1\end{array}$ & $\begin{array}{l}\text { viable cells \% } \\
2\end{array}$ & $\begin{array}{l}\text { viable cells \% } \\
3\end{array}$ & $\begin{array}{l}\text { viable cells } \% \\
\text { (mean) }\end{array}$ & $\begin{array}{l}\mathrm{IC}_{50} \text { value } \\
(\mu \mathrm{M})\end{array}$ \\
\hline Control & 100.00000 & 100 & 100 & 100 & - \\
\hline Quercetin & 101.44930 & 113.42975 & 117.4668 & 110.7 & - \\
\hline 1 & 36.56633 & 42.355372 & 52.196118 & 43.7 & 2.042 \\
\hline 2 & 62.76477 & 68.698347 & 74.668029 & 68.6 & - \\
\hline 3 & 55.74136 & 57.438017 & 60.980592 & 58 & - \\
\hline 4 & 31.21516 & 38.739669 & 44.53524 & 38.1 & 1.838 \\
\hline 5 & 101.08110 & 104.34783 & 102.79627 & 102.7 & - \\
\hline 6 & - & - & - & - & - \\
\hline
\end{tabular}

Table 6: The experimental biological activities, the calculated binding free energies (S) and the predicted biological activities

\begin{tabular}{lllll}
\hline Compounds & Experimental activity & S (Binding free energy) & Predicted activity & Residue \\
\hline 1 & 43.7 & -8.3382 & 45.6 & -1.9 \\
2 & 68.6 & -7.7526 & 61.6 & 7.0 \\
3 & 58.0 & -8.1026 & 52.0 & 6.0 \\
4 & 38.1 & -8.0665 & 53.0 & -14.9 \\
5 & 102.7 & -5.811 & 114.5 & -11.8 \\
6 & - & -6.5934 & - & - \\
Quercetin & 110.7 & -6.5222 & 95.1 & 15.6 \\
\hline
\end{tabular}

Table 7: The predicted active sites of the studied compounds within the target protein

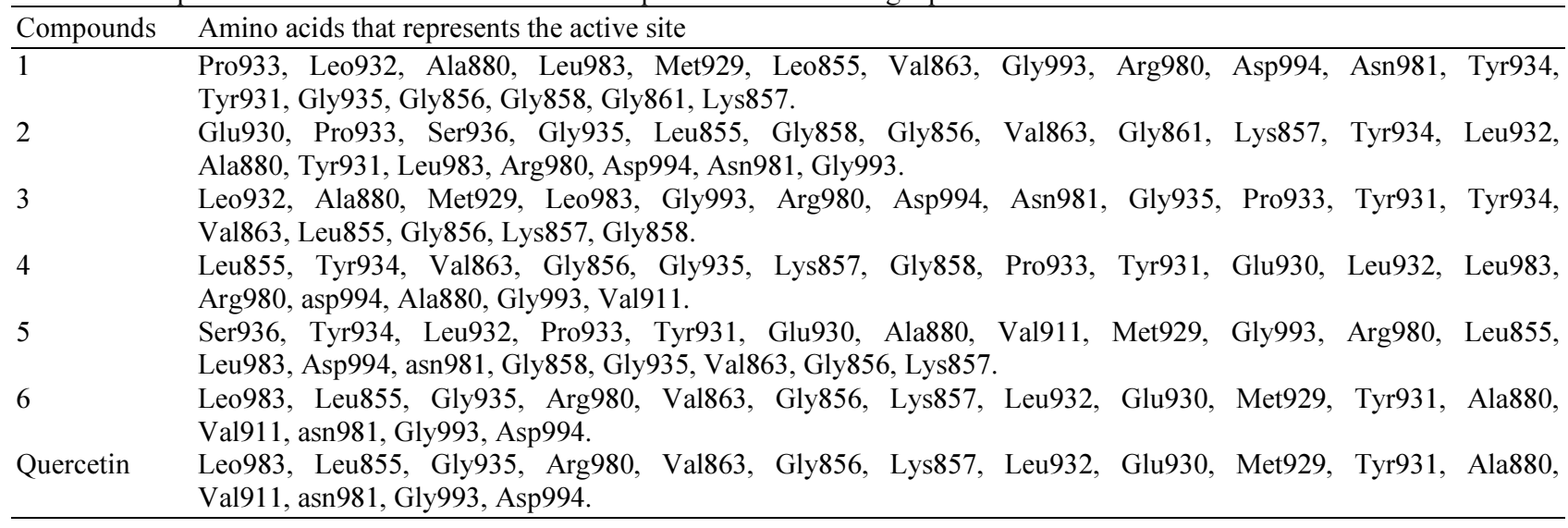

\section{Discussion}

\section{Synthesis}

The unique chemical structure and the characteristic distribution of the hydroxyl groups within the Quercetin molecule made direct conversion of the carbonyl group to its corresponding imine through general Schiff base synthesis method proposed by (Chakraborti et al., 2004) very difficult process, since the efficacy of this method involve the attack of highly electrophilic carbonyl group by highly neucleophilic amine group and thus the carbonyl should be activated first through the addition of Bronsted-Lowery or Lewis acid (LA) that catalyze the amine nucleophilic attack (Chakraborti et al., 2004; da Silva et al., 2011). This activation cannot be obtained within Quercetin molecule, because its carbonyl group form strong hydrogen bonding with C-5 hydroxyl group along with the presence of the $\mathrm{C} 2=\mathrm{C} 3$, result in strongly polar boundary structure of the Quercetin molecule in which $(+)$ charge on the ring oxygen atom and (-) charge on the carbonyl oxygen atom, thus the carbonyl oxygen atom became easily protonated (Heneczkowski et al., 2001). Once the acid catalyst being added, protonation of the carbonyl oxygen would take place and imine formation not possible. Therefore, in order to synthesize Quercetin Schiff base derivatives, Quercetin hydroxyl groups were first methylated, followed by thionation of the carbonyl group using Lawesson's reagent and finally reaction with different primary amines either directly or indirectly by treating the thionated product with methyl iodide in order to get the highly reacted 4thiomethyl iodide derivative followed by reaction with primary amine as described previously. 


\section{Identification}

The electronic spectra of quercetin and its 1-6 analogues show similar origin absorption bands of $\boldsymbol{\pi} \rightarrow \boldsymbol{\pi}^{*}$ transitions source and the differences within the position of these clearly indicate that structural modification within the Quercetin molecule had taken place. The blue shift within the spectra of compound 1 by $32 \mathrm{~nm}$ compared to Quercetin is attributed to the replacement of hydroxyl groups by methoxy groups. The hydroxy groups are responsible to the formation of quinine structure that extend the molecule $\pi$ system and subsequent red shifting of the absorption bands compared to the methoxy groups. In addition, methylation of hydroxyl groups especially that in position C-3 cause a change in the planarity of the B-ring with the rest of Quercetin molecule, which reduce the conjugation between ring $\mathrm{B}$ and $\mathrm{A}$ with a consequence reduction in the length of the chromophore and $\lambda \max$ ((Heim et al., 2002). On the other hand, a red shift is noticed in the spectrum of compound $\mathbf{2}$ compared to that of 1 by $58 \mathrm{~nm}$ caused by replacing the carbonyl group in compound 1 by thione group in compound 2 (Abboud et al., 1993). A blue shift by $16 \mathrm{~nm}$ when going from compound 1 to compound 3 where the position of the long absorption band shift from 339 to $323 \mathrm{~nm}$ and this is expected when the carbonyl group is replaced by an imino group, which usually lead to blue shift in the location of band associated with these group (Brodowska et al., 2016), while both compounds 5 and $\mathbf{6}$ show a red shifting in their long absorption band by about $80 \mathrm{~nm}$ compared to compound 3 , that is referred to the aryl group substitution on the imino group nitrogen atom which extend the $\pi$ system. Compound 4 shows a blue shift within band I by about $4 \mathrm{~nm}$ and $62 \mathrm{~nm}$ compared to compounds $\mathbf{1}$ and $\mathbf{2}$ respectively.

The mass spectra of the compounds 1-3, 5 and 6 characterized by molecular ion peaks of moderate abundances at $\mathrm{m} / \mathrm{z} 372,388,386.6,447.3$ and 537 corresponding to the calculated molecular weights of these compounds which are $372,388,386,447$ and 537 $\mathrm{g} / \mathrm{mole}$ respectively. This confirms the expected molecular structures of studied compounds.

The elemental analysis CHNS results of compounds 2, 3 and 4 revealed that these compounds were of good purity and in agreement with the expected chemical formula.

The important IR bands of quercetin and compounds 1-6 were shown in Table 3. The absence of the broad wide band of the hydroxyl group in the region 3437$1800 \mathrm{~cm}^{-1}$ (Paczkowska et al., 2015) of the Quercetin molecule along with the presence of a set of weak bands near $3000 \mathrm{~cm}^{-1}$ which attributed to the $\mathrm{C}-\mathrm{H}$ bond stretching vibration, indicates that all the hydroxyl groups were methylated. Compound $\mathbf{1}$ is also confirmed by the shift of the carbonyl band at $1666 \mathrm{~cm}^{-1}$ of the
Quercetin molecule to $1627 \mathrm{~cm}^{-1}$. On the other hand, the presence of bands at 1253 and $1260 \mathrm{~cm}^{-1}$ in compound 2 and 4 respectively confirms the presence of the $\mathrm{C}=\mathrm{S}$ (Larkin, 2011). Compound $\mathbf{3}$ shows two medium intensity bands at 3417 and $3387 \mathrm{~cm}^{-1}$ that are attributed to the antisymmetric and symmetric N-H stretching vibrations (Karabacak et al., 2009; Larkin, 2011). The disappearance of the $\mathrm{C}=\mathrm{S}$ band and appearance of the $\mathrm{C}=\mathrm{N}$ at $1627 \mathrm{~cm}^{-1}$ further confirms the formation of compound 3 such finding was also noticed within the IR spectra of compounds 5 and $\mathbf{6}$ and their $\mathrm{C}=\mathrm{N}$ bond gave peak at $1631 \mathrm{~cm}^{-1}$ (Mughal et al., 2006).

The ${ }^{1}$ HNMR spectrum of the quercetin (Table 4) involve the presence of three signals at 9.2, 10.4 and $12.4 \mathrm{ppm}$ that belongs to the phenolic protons at positions (3', 3, 4'), 7 and 5 respectively (Napolitano et $a l ., 2012)$. The disappearance of the hydroxyl signals in the ${ }^{1}$ HNMR spectra of the compounds 1-6 and the existence of new signals at $3.7 \mathrm{ppm}$ which assigned to the methoxy group confirm the methylation of these hydroxyls. Compound 3 shows broad signal at $6.9 \mathrm{ppm}$ that is due to the protons of the amino group, while the spectrum of compound 4 shows a signal at $1.68 \mathrm{ppm}$ due to the protons of the S-CH3 group (Breinmaier, 2003). The presence of the aromatic groups in the compound $\mathbf{5}$ and $\mathbf{6}$ give rise to signals at 7.14-7.35 ppm in compound 5 spectrums and a singlet at $7.07 \mathrm{ppm}$. Compound $\mathbf{6}$ also shows additional signals within the aliphatic proton region that belong to the three additional methoxy groups at 3.25-4.26 ppm.

\section{In Vitro Antiproliferative Activity}

The MDA-MB231 cell line has been chosen because TNBC represents a real challenge with its limited and non-specific treatment options, aggressiveness, high recurrence and poor survival rate. Patients usually suffer from relapse after 3-5 years of clinical intervention and resistance to chemotherapy can develop, so the need to develop new therapeutic agents to treat this breast cancer type is urgent (Dean and Rhodes, 2014). Since quercetin induces apoptosis and cell cycle arrest in TNBC cells and show advantages including no or less effect on normal cells, effectiveness in killing cancer cells, improvement in cancer relapse as well as enhancement of chemotherapy, it can be considered as a potential therapeutic agent against TNBC cells (Nguyen et al., 2017).

Results of the preliminary antiproliferative activity study of Quercetin and its derivatives (1-5) indicates that Quercetin have no antitumor activity against MDAMB231 cell line of breast cancer cells at tested concentrations, which agrees with previous studies (Ranganathan et al., 2015), however, Quercetin penta methyl ether derivatives (1-5) show antitumor activity against MDA-MB231 cell line of breast cancer cells 
suggesting a positive correlation between hydroxyl groups protection and antiproliferative activity against MDA-MB231 cell line.

The activity results show the importance of the presence of carbonyl group within the structure of the Quercetin pentamethylated molecule since compound 1 show more potent inhibition $(56.3 \%)$ than the thio analogue (2) and the imino analogues (3 and 5) which have potent inhibition values of $31.4 \%, 42 \%$ and $0 \%$ respectively. On the other hand, compound 4 gave even better results than compound 1 with $61.9 \%$ reduction to the growth of MDA-MB231 cell line, which could be attributed exhibited to the presence of iodine atom within its structure, probably in an antioxidant related mechanism (Rösner et al., 2016). $\mathrm{IC}_{50}$ value results shown in Table 4 clearly indicate that the novel compound 4 is more active than compound 1, although both are considered moderately active against MDAMB231 cell line (Prachayasittikul et al., 2015).

Results from Molecular docking assay correlate well with our practical finding and as could be seen from table 6 the program fairly predicted the relative activities of the studied compounds as compared with the experimental activity values. This is also clear in Fig. 3 which shows the relationship between the calculated $\mathrm{S}$ values and the experimentally measured activities. In this case the $R^{2}$ value of the correlation is 0.849 which is considered very well from the statistical point of view. The correlation equation is:

$y=27.258 x+272.89$

Where:

$\mathrm{y}=$ The biological activity

$\mathrm{x}=$ The calculated binding free energy

This equation is used in this study to predict the biological activities of the studied compounds depending on their calculated binding free energies which are the results of the docking calculations. The results are shown in Table 6 under the predicted activity column. The predicted values are fair and can give an approximate idea about the biological activities. The higher activity of compound 1 might be attributed to the presence of bulky groups that are substituted at the carbonyl group in the other compounds which create a steric hindrance. This will lead to a lack of fit in the cavity of the target protein and accordingly show lower interaction with protein.

\section{Conclusion}

On the basis of electronic, mass, IR and 1HNMR spectra and the elemental analysis the compounds 1-6 were characterized. The antiproliferative activity against MDA-MB-231 cell line have shown that the pentamethoxy Quercetin Schiff base and thiomethyl iodide derivatives have better antiproliferative activity than quercetin itself and that compounds $\mathbf{1}$ and $\mathbf{4}$ have potential anticancer therapeutic applications against the triple negative breast cancer type. Moreover, the molecular docking assay correlates well with our experimental findings.

\section{Acknowledgement}

The authors would like to express the thanks of gratitude to Dr. Ali Abdul Wahed Abdul Hussien in the department of chemistry and pure scince, college of education, university of Basrah for his help in performing the $\mathrm{IC}_{50}$ calculations regarding the anticancer activity.

\section{Author's Contributions}

Reham Adnan Taha: Msc student of Prof. Shaker Abdul Salim Neama and Assist prof. Rita S Elias, carried out the experiment and designing the table, figures.

Rita S. Elias: Supervisor of this work/including designing the project of the work, analyzed the data and wrote the paper.

Shaker Abdul Salim Neama: Supervisor of this work/designing the project of the work.

\section{Ethics}

This article is original and contains unpublished study. The corresponding author confirms that all the authors have read and approved the manuscript and no ethical issues involved.

\section{References}

Abboud, J.L., O. Mó, J.L. G. de Paz, M. Yanez and M.H. Esseffar et al., 1993. Thiocarbonyl versus Carbonyl Compounds: A comparison of intrinsic reactivities. J. Am. Chemical Society, 115: 12468-76.

DOI: 10.1021/ja00079a030

Abu Bakar, A., M.N. Akhtar, N. Mohd Ali, S.K. Yeap and C.K. Quah et al., 2018. Design, synthesis and docking studies of flavokawain $\mathrm{B}$ type chalcones and their cytotoxic effects on MCF-7 and MDAMB-231 cell lines. Molecules, 23: 1-14.

DOI: 10.3390/molecules23030616

Al-Jabban, S.M., X. Zhang, G. Chen, E.A. Mekuria and L.H. Rakotondraibe et al., 2015. Synthesis and antiproliferative effects of quercetin derivatives. Natural Products Communications, 10: 2113-8. DOI: $10.1177 / 1934578 X 1501001225$.

Amic, D., D. Davidovic-Amic, D. Beslo, V. Rastija and B. Lucic et al., 2007. SAR and QSAR of the antioxidant activity of flavonoids. Current Medicinal Chemistry, 14: 827-45.

DOI: $10.2174 / 092986707780090954$. 
Baker, W., G.G. Clarke and J.B. Harborne, 1954. Reactions of 4-thionchromones with aminocompounds and with methyl iodide. J. Chemical Society (Resumed). DOI: 10.1039/JR9540000998

Baker, W., J.B. Harborne and W.D. Ollis, 1952. Some properties of 4-thionflavone and its methiodide, and of 4-thionchromones. J. Chemical Society (Resumed). DOI: 10.1039/JR9520001303.

Breinmaier, E., 2003. Structure elucidation by NMR in organic chemistry. John Wiley@ Sons Ltd, Chichester. ISBN-10: 0470853069, pp: 258.

Brodowska, K., A. Sykuła, E. Garribba, E. ŁodygaChruścińska and M. Sójka, 2016. Naringenin Schiff base: antioxidant activity, acid-base profile and interactions with DNA. Transition Metal Chemistry, 41: 179-89. DOI: 10.1007/s11243-015-0010-7

Chakraborti, A.K., S. Bhagat and S. Rudrawar, 2004. Magnesium perchlorate as an efficient catalyst for the synthesis of imines and phenylhydrazones. Tetrahedron Lett., 45: 7641-44. DOI: $10.1016 /$ j.tetlet.2004.08.097

Chavez, K.J., S.V. Garimella and S. Lipkowitz, 2010. Triple negative breast cancer cell lines: one tool in the search for better treatment of triple negative breast cancer. Breast Disease, 32: 35-48. DOI: $10.3233 /$ bd-2010-0307

da Silva, C.M., D.L. da Silva, L.V. Modolo, R.B. Alves and M.A. de Resende et al., 2011. Schiff bases: A short review of their antimicrobial activities. J. Advanced Res., 2: 1-8. DOI: $10.1016 /$ j.jare.2010.05.004

Dajas, F., 2012. Life or death: Neuroprotective and anticancer effects of quercetin. $\mathrm{J}$. Ethnopharmacology, 143: 383-96. DOI: 10.1016/j.jep.2012.07.005

D'Andrea, G., 2015. Quercetin: A flavonol with multifaceted therapeutic applications? Fitoterapia, 106: 256-71. DOI: 10.1016/j.fitote.2015.09.018

Dean, S.J. and A. Rhodes, 2014. Triple negative breast cancer: The role of metabolic pathways. Malaysian J. Pathology, 36: 155-62.

Heim,. K.E., A.R. Tagliaferro and D.J. Bobilya, 2002. Flavonoid antioxidants: chemistry, metabolism and structure-activity relationships. J. Biochemistry, 13: 572-84. DOI: 10.1016/S0955-2863(02)00208-5

Heneczkowski, M., M. Kopacz, D. Nowak and A. Kuzniar, 2001. Infrared spectrum analysis of some flavonoids. Acta Poloniae Pharmaceutica, 58: 415-20.

Hertog, M.G.L., P.C.H. Hollman and M.B. Katan, 1992. Content of potentially anticarcinogenic flavonoids of 28 vegetables and 9 fruits commonly consumed in the Netherlands. J. Agricultural Food Chemistry, 40: 2379-83. DOI: $10.1021 / \mathrm{jf00024a011}$
Ice, C.H. and S.H. Wender, 1953. Quercetin and its glycosides in leaves of vaccinium myrtillus. J. Am. Chemical Society, 75: 50-52. DOI: $10.1021 /$ ja01097a013

Juvale, K., K. Stefan and M. Wiese. 2013. Synthesis and biological evaluation of flavones and benzoflavones as inhibitors of BCRP/ABCG2. Eur. J. Med. Chemistry, 67: 115-26.

DOI: 10.1016/j.ejmech.2013.06.035

Karabacak, M., M. Kurt, M. Çınar and A. Çoruh, 2009. Experimental (UV, NMR, IR and Raman) and theoretical spectroscopic properties of 2-chloro-6methylaniline. Molecular Physics, 107: 253-64. DOI: $10.1080 / 00268970902821579$

Larkin, P., 2011. Infrared and Raman spectroscopy: principles and spectral interpretation. Elsevier, USA. ISBN-10: 0128042095, pp: 239.

Massi, A., O. Bortolini, D. Ragno, T. Bernardi and G. Sacchetti et al., 2017. Research progress in the modification of quercetin leading to anticancer agents. Molecules, 22: 1270.

DOI: $10.3390 /$ molecules22081270

Moalin, M., G.P. Strijdonck, M. Beckers, G. Hagemen, and P. Borm et al., 2011. A planar conformation and the hydroxyl groups in the $\mathrm{B}$ and $\mathrm{C}$ rings play a pivotal role in the antioxidant capacity of quercetin and quercetin derivatives. Molecules, 16: 9636-50. DOI: $10.3390 /$ molecules 16119636

Mosmann, T., 1983. Rapid colorimetric assay for cellular growth and survival: application to proliferation and cytotoxicity assays. J. Immunological Methods, 65: 55-63. DOI: $10.1016 / 0022-1759(83) 90303-4$

Mughal, E.U., M. Ayaz, Z. Hussain, A. Hasan and A. Sadiq et al., 2006. Synthesis and antibacterial activity of substituted flavones, 4-thioflavones and 4-iminoflavones. J. Bioorganic Med. Chemistry, 14: 4704-11. DOI: 10.1016/j.bmc.2006.03.031

Napolitano, J.G., D.C. Lankin, S.N. Chen and G.F.J.M.R.I.C. Pauli, 2012. Complete 1H NMR spectral analysis of ten chemical markers of Ginkgo biloba. Magn. Reson. Chem.. 50: 569-75.

DOI: $10.1002 / \mathrm{mrc} .3829$

Nguyen, L.T., Y.H. Lee, A.R. Sharma, J.B. Park and S. Jagga et al., 2017. Quercetin induces apoptosis and cell cycle arrest in triple-negative breast cancer cells through modulation of Foxo3a activity. Korean J Physiol. Pharmacol., 21: 205-213.

DOI: 10.4196/kjpp.2017.21.2.205

Paczkowska, M., K. Lewandowska, W. Bednarski, M. Mizera and A. Podborska et al., 2015. Application of spectroscopic methods for identification (FT-IR, Raman spectroscopy) and determination (UV, EPR) of quercetin-3-O-rutinoside. Experimental and DFT based approach. Spectrochimica Acta Part A: Molecular Biomolecular Spectroscopy, 140: 132-39. DOI: $10.1016 /$ j.saa.2014.12.050 
Picq, M., A.F. Prigent, G. Nemoz, A.C. Andre and H. Pacheco et al., 1982. Pentasubstituted quercetin analogs as selective inhibitors of particulate $3 ', 5^{\prime}-$ cyclic-AMP phosphodiesterase from rat brain. J. Medicinal Chemistry, 25: 1192-98.

DOI: $10.1021 / \mathrm{jm} 00352 \mathrm{a} 019$

Pietta, P.G., 2000. Flavonoids as antioxidants. J. Natural Products, 63: 1035-42. DOI: 10.1021/np9904509

Prachayasittikul, V., R. Pingaew, N. Anuwongcharoen, A. Worachartcheewan and C. Nantasenamat et al., 2015. Discovery of novel 1,2,3-triazole derivatives as anticancer agents using QSAR and in silico structural modification. SpringerPlus, 4: 571. DOI: $10.1186 / \mathrm{s} 40064-015-1352-5$

Procházková, D., I. Boušová and N. Wilhelmová, 2011. Antioxidant and prooxidant properties of flavonoids. Fitoterapia, 82: 513-23. DOI: $10.1016 /$ j.fitote .2011 .01 .018

Rakha, E.A., J.S. Reis-Filho and I.O. Ellis, 2008. Basallike breast cancer: A critical review. J. Clinical Oncology: Official J. Am. Society Clinical Oncology, 26: 2568-81.

DOI: $10.1200 /$ jco.2007.13.1748

Ramos, F., Y. Takaishi, M. Shirotori, Y. Kawaguchi and K. Tsuchiya et al., 2006. Antibacterial and antioxidant activities of quercetin oxidation products from yellow onion (Allium cepa) Skin. J. Agric. Food Chem., 54: 3551-3557. DOI: $10.1021 /$ jf060251c

Ranganathan, S., D. Halagowder and N.D.J.P.O. Sivasithambaram. 2015. Quercetin suppresses twist to induce apoptosis in MCF-7 breast cancer cells. PLoS One, 10: e0141370.

DOI: 10.1371 journal.pone.0141370

Rauf, A., M. Imran, I.A. Khan, M. Ur-Rehman and S.A. Gilani et al., 2018. Anticancer potential of quercetin: A comprehensive review. Phytotherapy Res., 32: 1-22. DOI: 10.1002/ptr.6155
Ravishankar, D., K.A. Watson, S.Y. Boateng, R.J. Green and F. Greco et al., 2015. Exploring quercetin and luteolin derivatives as antiangiogenic agents. Eur. J. Medicinal Chemistry, 97: 259-74.

DOI: $10.1016 /$ j.ejmech.2015.04.056

Rösner, H., W. Möller and S. Groebner, 2016. Antiproliferative cytotoxic effects of molecular iodine, povidone-iodine and Lugol's solution in different human carcinoma cell lines. Oncol Lett., 12: 2159-2162. DOI: 10.3892/ol.2016.4811

Thomsen, I., K. Clausen, S. Scheibye and S.O. Lawesson, 1984. Thionatio with 2,4-bis(4methoxypheny)-1,3,2,4- dithiadiphosphetane 2,4disulfide: N-methylthiopyrrolidone[2Pyrrolidinethione, 1-methyl-]. Organic Syntheses, 62: 158. DOI: 10.1002/047084289X.rb170

Walle, T., 2009. Methylation of dietary flavones increases their metabolic stability and chemopreventive effects. Int. J. Molecular Sci., 10: 5002-19. DOI: 10.3390/ijms 10115002

Wang, L., Y.C. Tu, T.W. Lian, J.T. Hung and J.H. Yen et al., 2006. Distinctive antioxidant and antiinflammatory effects of flavonols. J. Agricultural Food Chemistry, 54: 9798-804. DOI: $10.1021 /$ jf0620719

Yuan, J., I.L. Wong, T. Jiang, S.W. Wang and T. Liu et al., 2012. Synthesis of methylated quercetin derivatives and their reversal activities on P-gp- and BCRP-mediated multidrug resistance tumour cells. Eur. J. Med. Chem., 54: 413-22. DOI: 10.1016/j.ejmech.2012.05.026

Zhi-Hao, S., N.G. Li, Y.P. Tang, Q.P. Shi and W. Zhang et al., 2014. Synthesis, biological evaluation and SAR analysis of O-alkylated analogs of quercetin for anticancer. Bioorganic Medicinal Chemistry Lett., 24: 4424-27.

DOI: $10.1016 /$ j.bmcl.2014.08.006 